See discussions, stats, and author profiles for this publication at: https://www.researchgate.net/publication/293643158

\title{
Closed-loop supply chains: What reverse logistics factors influence performance?
}

Article in International Journal of Production Economics · February 2016

DOI: 10.1016/j.jpe.2016.01.012

CITATIONS

54

3 authors:

Salvatore Cannella

University of Catania

68 PUBLICATIONS 968 CITATIONS

SEE PROFILE

Jose M. Framinan

Universidad de Sevilla

197 PUBLICATIONS 3,480 CITATIONS

SEE PROFILE
READS

834

Manfredi Bruccoleri

Università degli Studi di Palermo

60 PUBLICATIONS 1,004 CITATIONS

SEE PROFILE

Some of the authors of this publication are also working on these related projects:

Collaboration strategies in decentralized supply chains with partial information sharing View project

Models and algorithms for the order scheduling problems considering setup times View project 


\title{
IClosed-loop supply chains: What reverse logistics factors influence performance?
}

\begin{abstract}
This paper analyses the inventory and order flow dynamics in closed-loop supply chains (CLSCs). In this kind of supply chains the reverse flow of materials entering the system for recycling purposes complicates the way in which inventories should be managed and replenishment policies should be designed. Specifically, we analyse the relationships between some reverse logistics' factors (remanufacturing lead-time, return rate of recycled products, reverse order policy, and number of supply chain tiers) on the order and inventory variance amplification. We firstly perform a systematic literature review of the related studies. Secondly, by adopting a difference equation math approach and design of experiment we perform a robust what-if analysis of a CLSC under a variety of operational and market conditions. Results show that, ceteris paribus, CLSC outperforms a forward supply chain, both in mono-echelon and multi-echelon structures and under both stationary and turbulent market demands. Furthermore, reducing remanufacturing lead-time and promoting information transparency may be crucial to improve CLSC dynamics. Finally, we use the research findings to provide interesting managerial consideration about how to reduce unnecessary operational members' costs.
\end{abstract}

Keywords: Supply chain dynamics, reverse logistics, remanufacturing lead time, bullwhip effect, systematic literature review, simulation.

\section{INTRODUCTION}

Sustainable Supply Chain refers to the management of material flows, information and funds, as well as cooperation between firms along the supply chain (SC) that simultaneously consider the three dimensions of sustainable development: environmental, social and economic (Brandenburg et al. 2014, Meixell and Luoman 2015, Eskandarpour 2015). A firm can use a sustainable program as a strategic tool not only for environmental improvement, but also to enhance the image of its brand, generate revenue, serve its customers, and reduce production costs (Qiang et al. 2013).

A type of sustainable SC is the Closed Loop Supply Chain (CLSC), (Ramezani et al. 2014, Govindan et al. 2015) designed to manage the recycling and recovery process of end-of-life products (Guide and Van Wassenhove 2009, Das and Posinasetti 2015). A CLSC generally involves a manufacturer taking care for the reverse logistics process. The goods are returned and recovered directly by the original manufacturer or through indirect channels (Ashayeri et al. 2015). All the returned goods are resold in primary or secondary market after necessary disposition (Turrisi et al. 2013). Essentially, a CLSC extends the normal forward SC by including reverse SC channels for product return, recycling/recovery, remanufacturing, and resale (He 2015). 
In the last decade, studying CLSC has become a major area of SC management literature and increasing attention has been devoted to the understanding, management, and improvement of this type of SC structure (Mollenkopf et al., 2011, Adenso-Díaz et al., 2012, He 2015, Devika et al. 2015). The focus of most studies on CLSC mainly relies on assessing their effective performance in terms of economical sustainability (Georgiadis and Besiou, 2010), environmental sustainability (Paksoy et al., 2011, Jayaram and Avittathur 2015), and operational performance (Zhou and Piramuthu, 2013). Regarding this last stream, the majority of the works focus on the optimization of the remanufacturing process (Zhou and Piramuthu, 2013). On the contrary, few efforts explore the dynamics of CLSC in terms of inventory and order variations. In fact, the reverse flow of products entering the chain may impacts the dynamics of SC members' inventories and their order quantities (Adenso-Diaz et al. 2012, Turrisi et al. 2013), and may amplify or moderate detrimental time-varying phenomena, such as the bullwhip effect and inventory instability (Disney and Towill 2003). However, very few studies discuss the effect of the reverse logistics on the bullwhip effect in CLSC and, furthermore, their conclusions are quite contrasting (see e.g., Zhou and Disney 2006, Huang and Wang 2007, Qingli et al. 2008, Ding and Gan 2009, Adenso-Dìaz et al. 2012, Turrisi et al. 2013, Corus et al. 2014, among others). Some studies affirm that return flow limits the bullwhip effect and stabilize the dynamics of SC inventories. On the contrary, other studies show that a CLSC is more prone to the bullwhip with respect to the forward SC.

All of the studies consider different SC configurations and modelling assumptions (i.e., number of echelons) and thus the results are not really comparable. Another problem is the key parameters of the inventory management in CLSCs (i.e., remanufacturing lead time, return rate, final consumer's demand pattern etc.). Most studies pay little attention to the potential impact of these parameters on the dynamics of CLSC. A further gap concern the replenishment rules adopted for the management of CLSC. There is not a common agreement about how different ad-hoc order policies may alter CLSC performance.

Motivated by these conflicting argumentations and contrasting results, but also by the practical relevance of better comprehending this theme, in this paper we aim at contributing to the existing knowledge on reverse logistics and supply chains by rigorously investigating the dynamics of a CLSC under a variety of order policies, market and operational conditions; we also aim at offering practical suggestions for supply chain managers to properly design order and inventory policies in reverse logistics contexts. To this purpose, we firstly perform a systematic literature review to select reverse logistics specific factors that could potentially influence CLSC dynamics. Secondly, through a differential equation systems approach we model different configurations of CLSC and by adopting a rigorous design of experiment we analyse the effect of four logistics' factors on the dynamics response. More specifically, we test the effect of (1) the return rate of recycled products, (2) the remanufacturing lead-time performance, (3) the number of echelons and (4) and two different order policies properly designed for inventory management in CLSCs, characterised by an increasing level of information visibility of the reverse logistics process, namely the Tang and Naim (2004) order policy and the Zhou and Disney (2006) order policy. We assess the performance in terms of bullwhip effect and inventory stability by adopting two well-known non-financial performance metrics (i.e., Order Rate Variance Ratio and Inventory Variance Ratio). 
Simulation output shows how the existence of a return flow positively affects both the inventory variance and the bullwhip effect independently of the number of echelons and the market conditions. On the contrary, an increasing remanufacturing lead-time negatively affects both the order and inventory stability. Concerning the inventory policy, results show how higher information transparencies increase dynamics performance. Our findings are relevant for managers. In general, we show that a CLSC may be adopted not only for meeting the advocated benefits provided by sustainability, but also because, this structure may act as a bullwhip-limiting strategy.

The rest of the paper is organised as follows: Section 2 presents a literature review. Section 3 describes the methodological approach. Section 4 presents the assumptions made for this work and the metrics selected. Section 5 presents the design of experiments and the numerical results. Section 6 presents findings and managerial implications. Finally, Section 7 presents conclusions, limitation and further research directions.

\section{CLOSED-LOOP SUPPLY CHAIN: A SYSTEMATIC LITERATURE REVIEW}

We conduct a review of the literature on dynamics analysis in CLSC by adopting the systematic review framework for management and organization studies proposed by Denyer and Tranfield (2009). This framework is based on four core principles adopted in medical science's reviews, i.e., "Transparency", "Inclusivity", "Explanatory" and "Heuristic Nature". These principles are applied in the following 5 steps. (1) Question Formulation, (2) Locating Studies, (3) Selection and evaluation, (4) Analysis and Synthesis, and (5) Results Reporting.

\subsection{Step 1: Question Formulation}

The first step is to establish the focus of the research. In our work we aim at collecting all existing studies on dynamics analysis of CLSC. Particularly, we want to identify which SC parameters may influence members' operational performance.

\subsection{Step 2: Locating Studies}

In order to conduct an exhaustive research, we use the scientific articles databases identified by the "MIT Libraries' Research Guides" for studies on the topic "Management \& Business / Industries" (http://libguides.mit.edu/industries). These are ABI/Inform Global, Business Source Complete, JSTOR Scholarly Journal Archive, Scopus, and Web of Science.

We use the same search string for each database, (i.e., "Closed Loop Supply Chain" OR "Remanufacturing" OR "Reverse Logistics") AND ("Bullwhip" OR "Demand amplification" OR "Forrester effect" OR "Dynamic behaviour" OR “APIOBPCS" OR “Order rate variance”). A total of 40 articles were found searching in the five databases. It is worth to mention that Business Source Complete and JSTOR Scholarly Journal Archive did not show any results for the used search string.

\subsection{Step 3: Study selection/exclusion and evaluation}


The third step concerns the explicit elucidation about the selection/exclusion criteria of the review. Table 1 reports the 40 articles obtained. Articles are categorized by authors and year of publication, research methodology adopted, databases, article contribution to the literature, and the reason(s) behind their exclusion from the review.

Table 1 - Systematic Literature Review

\begin{tabular}{|c|c|c|c|c|c|c|c|}
\hline $\begin{array}{l}N^{\circ} \text { Article } \\
(\text { Typology) }\end{array}$ & Authors (Year) & Methodology & 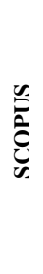 & 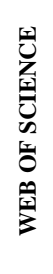 & 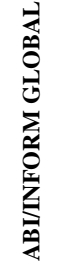 & Main Contribution & $\begin{array}{l}\text { Reason(s) behind Exclusion } \\
\text { Keyword to justify Exclusion }\end{array}$ \\
\hline $\begin{array}{l}{[1]} \\
\text { Journal }\end{array}$ & $\begin{array}{l}\text { Shi et al. } \\
2015\end{array}$ & $\begin{array}{l}\text { Math Model, } \\
\text { Simulation }\end{array}$ & $\mathrm{x}$ & & & $\begin{array}{l}\text { - Impact of a dynamic remanufacturing duopoly game model with } \\
\text { different competition and heterogeneous players }\end{array}$ & $\begin{array}{l}\text { - Lack of specific insights on the influence of } \\
\text { reverse logistics factors on dynamic behaviour }\end{array}$ \\
\hline $\begin{array}{l}{[2]} \\
\text { Journal }\end{array}$ & $\begin{array}{l}\text { Yuan et al. } \\
2015\end{array}$ & $\begin{array}{l}\text { System Dynamics, } \\
\text { Simulation }\end{array}$ & $\mathrm{x}$ & & & $\begin{array}{l}\text { - Impact of the products (parts) recyclers influences the loop SC } \\
\text { distribution system }\end{array}$ & $\begin{array}{l}\text { - Lack of specific insights on the influence of } \\
\text { reverse logistics factors on dynamic behaviour }\end{array}$ \\
\hline [3] & $\begin{array}{l}\text { Ma et al. } \\
2014\end{array}$ & $\begin{array}{l}\text { Discrete Event } \\
\text { Simulation }\end{array}$ & $\mathrm{X}$ & & & $\begin{array}{l}\text { - Comparison between push- and pull-controlled hybrid production } \\
\text { systems with the traditional one, based on the total inventory cost, } \\
\text { and manufacturing and remanufacturing order variances }\end{array}$ & - Selected \\
\hline $\begin{array}{l}{[4]} \\
\text { Journal }\end{array}$ & $\begin{array}{l}\text { Jing, et al. } \\
2013\end{array}$ & Control Theory & $\mathrm{X}$ & & & $\begin{array}{l}\text { - Modeling and analysis method applied to establish z-domain of } \\
\text { single-echelon CLSC to describe and control the bullwhip effect. }\end{array}$ & $\begin{array}{l}\text { - Lack of specific insights on the influence of } \\
\text { reverse logistics factors on dynamic behaviour }\end{array}$ \\
\hline $\begin{array}{l}{[5]} \\
\text { Journal }\end{array}$ & $\begin{array}{l}\text { Turrisi et al. } \\
2013\end{array}$ & $\begin{array}{l}\text { Math Model, DOE, } \\
\text { System Dynamics } \\
\text { Simulation }\end{array}$ & $\mathrm{X}$ & & & $\begin{array}{l}\text { - Novel replenishment rule proposed to coordinate the upstream and } \\
\text { downstream flows in a CLSC. } \\
\text { - Impact of reverse flow in a CLSC in terms of the serviceable } \\
\text { inventory variance. }\end{array}$ & Selected \\
\hline $\begin{array}{l}{[6]} \\
\text { Journal }\end{array}$ & $\begin{array}{l}\text { Lehr et al. } \\
2013\end{array}$ & $\begin{array}{l}\text { System Dynamics } \\
\text { Simulation }\end{array}$ & $\mathrm{X}$ & $\mathrm{X}$ & $\mathrm{X}$ & $\begin{array}{l}\text { - System dynamics model to test different value recovery strategies in } \\
\text { a CLSC setting. } \\
\text { — Insights on Strategies for the collection and value recovery. }\end{array}$ & $\begin{array}{l}\text { Lack of specific insights on the influence of } \\
\text { reverse logistics factors on dynamic behaviour }\end{array}$ \\
\hline $\begin{array}{l}{[7]} \\
\text { Book }\end{array}$ & $\begin{array}{l}\text { Das and Dutta, } \\
2013\end{array}$ & $\begin{array}{l}\text { System Dynamics } \\
\text { Simulation }\end{array}$ & $\mathrm{X}$ & & & $\begin{array}{l}\text { - Impact of the long-term behavior of a multi- echelon forward- } \\
\text { reverse SC with fuzzy demand and fuzzy collection rate } \\
\text { - Insights on variation of orders at both retailer and distributor in } \\
\text { forward SC and CLSC }\end{array}$ & $\begin{array}{l}\text { Lack of specific insights on the influence of } \\
\text { reverse logistics factors on dynamic behaviour }\end{array}$ \\
\hline $\begin{array}{l}{[8]} \\
\text { Book }\end{array}$ & Das \& Dutta, 2012 & $\begin{array}{l}\text { System Dynamics } \\
\text { Simulation }\end{array}$ & $\mathrm{X}$ & & & $\begin{array}{l}\text { - Impact of long-term behavior of a multi- echelon forward-reverse } \\
\text { SC with fuzzy demand and fuzzy collection rate } \\
\text { - Insights on variation of orders at both retailer and distributor in } \\
\text { forward SC and CLSC }\end{array}$ & Selected \\
\hline $\begin{array}{l}{[9]} \\
\text { Conference }\end{array}$ & $\begin{array}{l}\text { Wan and } \mathrm{Li} \\
2012\end{array}$ & $\begin{array}{l}\text { System Dynamics } \\
\text { Simulation }\end{array}$ & $\mathrm{X}$ & & & $\begin{array}{l}\text { - CLSC model to analyze the influence of reverse logistics for } \\
\text { bullwhip effect. }\end{array}$ & $\begin{array}{l}\text { - Lack of specific insights on the influence of } \\
\text { reverse logistics factors on dynamic behaviour }\end{array}$ \\
\hline $\begin{array}{l}{[10]} \\
\text { Journal }\end{array}$ & $\begin{array}{l}\text { Adenso-Díaz et al } \\
2012\end{array}$ & $\begin{array}{l}\text { Simulation } \\
\text { Technique \& } \\
\text { Statistical Analysis }\end{array}$ & $\mathrm{X}$ & $\mathrm{X}$ & $\mathrm{X}$ & $\begin{array}{l}\text { - Analysis of the influence of } 12 \text { factors identified as significant with } \\
\text { regard to the bullwhip in both forward and reverse SC. }\end{array}$ & Selected \\
\hline $\begin{array}{l}{[11]} \\
\text { Conference }\end{array}$ & $\begin{array}{l}\text { Zhang } \\
2011\end{array}$ & Control Theory & $\mathrm{x}$ & & & $\begin{array}{l}\text { - Insights on } \mathrm{H} \infty \text { robust control method in CLSC to reduce bullwhip } \\
\text { effect under two forecasting methods of market demand: Moving } \\
\text { Average and Exponential Smoothing. }\end{array}$ & Selected \\
\hline $\begin{array}{l}{[12]} \\
\text { Book }\end{array}$ & $\begin{array}{l}\text { Hao } \\
2011\end{array}$ & N. A. & $\mathrm{X}$ & $\mathrm{x}$ & & $\begin{array}{l}\text { - Analysis of internal operation and external relevance of } 8 \text { sub- } \\
\text { systems related to a mechanism of time-efficiency oriented after- } \\
\text { sale logistics operation. }\end{array}$ & - "Bullwhip" is present only in the Keywords \\
\hline $\begin{array}{l}\text { [13] } \\
\text { Conference }\end{array}$ & Wu and Tang, 2010 & $\begin{array}{l}\text { Mathematical } \\
\text { Statistics }\end{array}$ & & $\mathrm{X}$ & & $\begin{array}{l}\text { - Quantitative model for analyzing the bullwhip effect in CLSC. } \\
\text { - Impact of return ratio, lead time and demand forecast on bullwhip. }\end{array}$ & $\begin{array}{l}\text { - Lack of specific insights on the influence of } \\
\text { reverse logistics factors on dynamic behaviour }\end{array}$ \\
\hline $\begin{array}{l}{[14]} \\
\text { Conference }\end{array}$ & $\begin{array}{l}\text { Xionget al. } \\
2010\end{array}$ & $\begin{array}{l}\text { Mathematical } \\
\text { Model }\end{array}$ & $\mathrm{X}$ & & & $\begin{array}{l}\text { - Comparison of the Bullwhip Effect between the Forward Logistics } \\
\text { and the CLSC. } \\
\text { - Reverse Logistics exacerbate the Bullwhip Effect }\end{array}$ & - Published in Chinese language \\
\hline $\begin{array}{l}{[15]} \\
\text { Conference }\end{array}$ & Guo and Sun 2010 & Control Theory & $\mathrm{X}$ & & $\mathrm{x}$ & $\begin{array}{l}\text { - Insights on dual-channel CLSC model with B2B E-Market and the } \\
\text { reverse logistics. } \\
\text { - Insights on } \mathrm{H} \infty \text { control method of the system under the worst } \\
\text { fluctuation of demand. }\end{array}$ & $\begin{array}{l}\text { Lack of specific insights on the influence of } \\
\text { reverse logistics factors on dynamic behaviour }\end{array}$ \\
\hline $\begin{array}{l}{[16]} \\
\text { Journal }\end{array}$ & $\begin{array}{l}\text { Pati et al. } \\
2010\end{array}$ & Statistical Analysis & $\mathrm{X}$ & & & $\begin{array}{l}\text { - Insights on bullwhip in a six echelon CLSC for recycling of } \\
\text { products. } \\
\text { - Impact of degree of segregation on bullwhip CLSC }\end{array}$ & Selected \\
\hline $\begin{array}{l}{[17]} \\
\text { Conference }\end{array}$ & $\begin{array}{l}\text { Tejeida et al. } \\
2010\end{array}$ & Fractal Analysis & $\mathrm{X}$ & & & $\begin{array}{l}\text { - Bullwhip in an after-sales spare part CLSC in telecom firms via } \\
\text { fractal analysis. }\end{array}$ & $\begin{array}{l}\text { Lack of specific insights on the influence of } \\
\text { reverse logistics factors on dynamic behaviour }\end{array}$ \\
\hline $\begin{array}{l}{[18]} \\
\text { Conference }\end{array}$ & $\begin{array}{l}\text { Guo } \\
2010\end{array}$ & Control Theory & $\mathrm{X}$ & & & $\begin{array}{l}\text { - Formalization of a linear matrix inequality to study the operation of } \\
\text { the CLSC networks with the third party reverse providers. } \\
\text { - Presentation of a new method to study the stability of CLSC } \\
\text { networks and bullwhip effects. }\end{array}$ & - Similar insights to those in article 28 \\
\hline $\begin{array}{l}{[19]} \\
\text { Conference }\end{array}$ & $\begin{array}{l}\text { Wang and Ding } \\
2009\end{array}$ & $\begin{array}{l}\text { System Dynamics } \\
\text { Simulation }\end{array}$ & $\mathrm{X}$ & $\mathrm{X}$ & & $\begin{array}{l}\text { - Impact of a reverse logistics for direct reuse productions on } \\
\text { dynamics of the SC. } \\
\text { - Influence of the return rate on the dynamic of the chain. }\end{array}$ & Selected \\
\hline [20] & $\begin{array}{l}\text { Ding and Gan } \\
2009\end{array}$ & System Dynamics & $\mathrm{x}$ & $\mathrm{X}$ & & — Traditional/ CLSC model under APIOBPCS. & Selected \\
\hline
\end{tabular}




\begin{tabular}{|c|c|c|c|c|c|c|c|}
\hline Conference & & Simulation & & & & $\begin{array}{l}\text { - Effect of remanufacture and the return ratio on oscillation and } \\
\text { amplification effect. } \\
\text { - Influence of the return rate on the dynamic of the chain. }\end{array}$ & \\
\hline $\begin{array}{l}{[21]} \\
\text { Conference }\end{array}$ & $\begin{array}{l}\text { Gong et al. } \\
2009\end{array}$ & $\begin{array}{l}\text { Mathematical } \\
\text { Model }\end{array}$ & $\mathrm{X}$ & $\mathrm{X}$ & & $\begin{array}{l}\text { - Presentation of a fuzzy chance constraint programming approach } \\
\text { applied for the optimization in the location-allocation problem }\end{array}$ & - "Bullwhip" is present only in the Abstract \\
\hline $\begin{array}{l}{[22]} \\
\text { Conference }\end{array}$ & $\begin{array}{l}\text { Hua } \\
2009\end{array}$ & $\begin{array}{l}\text { Control Theory \& } \\
\text { Simulation } \\
\text { Technique }\end{array}$ & $\mathrm{x}$ & $\mathrm{X}$ & & $\begin{array}{l}\text { - Effects of remanufacturing lead-time and return rate on the } \\
\text { bullwhip. } \\
\text { - Comparison of a CLSC with a forward SC in terms of bullwhip } \\
\text { effect. }\end{array}$ & - Similar insights to those in article 34 \\
\hline $\begin{array}{l}{[23]} \\
\text { Journal }\end{array}$ & $\begin{array}{l}\text { Ge and Huang } \\
2009\end{array}$ & Control Theory & $\mathrm{x}$ & & & $\begin{array}{l}\text { - Formalization of a CLSC with remanufacturing self-recall and } \\
\text { outsourcing subsystems. } \\
\text { - Proposition of a control law for CLSC. }\end{array}$ & - Published in "Chinese" language \\
\hline $\begin{array}{l}{[24]} \\
\text { Conference }\end{array}$ & $\begin{array}{l}\text { Guo, et al. } \\
2008\end{array}$ & Control Theory & & $\mathrm{X}$ & & $\begin{array}{l}\text { - Formalization of two CLSC networks with third party reverse } \\
\text { providers including the dynamic controlling process for both normal } \\
\text { manufacturing, remanufacturing and inventory }\end{array}$ & - Similar insights to those in article 26 \\
\hline $\begin{array}{l}{[25]} \\
\text { Conference }\end{array}$ & $\begin{array}{l}\text { Huang and Liu } \\
2008\end{array}$ & $\begin{array}{l}\text { System Dynamics } \\
\text { Simulation }\end{array}$ & $\mathrm{x}$ & $\mathrm{X}$ & & $\begin{array}{l}\text { - Effect of remanufacture, remanufacturing lead-time and the return } \\
\text { rate on the inventory variance and bullwhip effect. }\end{array}$ & Selected \\
\hline $\begin{array}{l}{[26]} \\
\text { Conference }\end{array}$ & Guo 2008b & Control Theory & $\mathrm{x}$ & $\mathrm{x}$ & & $\begin{array}{l}\text { - Presentation of a new method to study the stability of CLSC } \\
\text { networks and restrain their bullwhip effects. }\end{array}$ & - Similar insights to those in article 28 \\
\hline $\begin{array}{l}\text { [27] } \\
\text { Conference }\end{array}$ & $\begin{array}{l}\text { Qingli et al. } \\
2008\end{array}$ & $\begin{array}{l}\text { System Dynamics } \\
\text { Simulation }\end{array}$ & $\mathrm{X}$ & $\mathrm{X}$ & & $\begin{array}{l}\text { - Comparison of an "open loop" reverse SC with CLSC with } \\
\text { environmental protection policies (EPP) and capacity planning } \\
\text { strategies }\end{array}$ & Selected \\
\hline $\begin{array}{l}{[28]} \\
\text { Conference }\end{array}$ & $\begin{array}{l}\text { Guo } \\
2008 b\end{array}$ & Control Theory & $\mathrm{x}$ & $\mathrm{X}$ & & $\begin{array}{l}\text { - Presentation of a new method to study the stability of CLSC } \\
\text { networks and restrain their bullwhip effects. }\end{array}$ & $\begin{array}{l}\text { - Lack of specific insights on the influence of } \\
\text { reverse logistics factors on dynamic behaviour }\end{array}$ \\
\hline $\begin{array}{l}{[29]} \\
\text { Journal }\end{array}$ & $\begin{array}{l}\text { Guo and Xu } \\
2008\end{array}$ & Control Theory & $\mathrm{x}$ & & & $\begin{array}{l}\text { - Presentation of an } \mathrm{H} \text { infinity control strategy to reduce bullwhip } \\
\text { effect }\end{array}$ & $\begin{array}{l}\text { - Lack of specific insights on the influence of } \\
\text { reverse logistics factors on dynamic behaviour } \\
\text { - Similar insights to those in article } 32\end{array}$ \\
\hline $\begin{array}{l}{[30]} \\
\text { Journal }\end{array}$ & $\begin{array}{l}\text { You, Sui \& Huo } \\
(2007\end{array}$ & Control Theory & $\mathrm{x}$ & & & $\begin{array}{l}\text { - Adoption of a z-transformation model to analyze the bullwhip effect } \\
\text { for multi-echelon inventory system under CLSC }\end{array}$ & $\begin{array}{l}\text { Lack of specific insights on the influence of } \\
\text { reverse logistics factors on dynamic behaviour }\end{array}$ \\
\hline $\begin{array}{l}{[31]} \\
\text { Conference }\end{array}$ & $\begin{array}{l}\text { Guo and Huang } \\
\text { 2006b }\end{array}$ & Control Theory & & $\mathrm{X}$ & & $\begin{array}{l}\text { - Presentation of an } \mathrm{H} \text { infinity control strategy to reduce bullwhip } \\
\text { effect }\end{array}$ & $\begin{array}{l}\text { Lack of specific insights on the influence of } \\
\text { reverse logistics factors on dynamic behaviour } \\
\text { Similar insights to those in article } 32\end{array}$ \\
\hline $\begin{array}{l}\text { [32] } \\
\text { Conference }\end{array}$ & $\begin{array}{l}\text { Guo and Huang } \\
\text { 2006a }\end{array}$ & Control Theory & $\mathrm{x}$ & $\mathrm{X}$ & & $\begin{array}{l}\text { - Adoption of a discrete-time transfer function of CLSC networks as a } \\
\text { method to quantify the bullwhip effect }\end{array}$ & $\begin{array}{l}\text { - Lack of specific insights on the influence of } \\
\text { reverse logistics factors on dynamic behaviour }\end{array}$ \\
\hline $\begin{array}{l}{[33]} \\
\text { Journal }\end{array}$ & $\begin{array}{l}\text { Zanoni et al. } \\
2006\end{array}$ & $\begin{array}{l}\text { Discrete-Event } \\
\text { based Simulation }\end{array}$ & $\mathrm{x}$ & $\mathrm{X}$ & $\mathrm{x}$ & $\begin{array}{l}\text { - Comparison between four different inventory policies, in terms of } \\
\text { economic consequences and bullwhip effect. } \\
\text { - Formalization of management guidelines for hybrid inventory } \\
\text { system }\end{array}$ & Selected \\
\hline$[34]$ & $\begin{array}{l}\text { Zhou and Disney } \\
2006\end{array}$ & Control Theory & $\mathrm{x}$ & $\mathrm{X}$ & $\mathrm{x}$ & $\begin{array}{l}\text { - Effects of a combined "in-use" and remanufacturing lead-time and } \\
\text { the return rate on the inventory variance and bullwhip effect. }\end{array}$ & Selected \\
\hline $\begin{array}{l}{[35]} \\
\text { Conference }\end{array}$ & $\begin{array}{l}\text { Zhou et al. } \\
2005\end{array}$ & Control Theory & $\mathrm{x}$ & & & $\begin{array}{l}\text { - Comparison of a forward SC with a CLSC and impact of returns on } \\
\text { inventory variance and bullwhip effect. . }\end{array}$ & - Extended version: article 36 \\
\hline $\begin{array}{l}{[36]} \\
\text { Journal }\end{array}$ & $\begin{array}{l}\text { Zhou et al. } \\
2006\end{array}$ & $\begin{array}{l}\text { Control Theory \& } \\
\text { System Dynamics } \\
\text { Simulation }\end{array}$ & $\mathrm{x}$ & $\mathrm{X}$ & $\mathrm{X}$ & $\begin{array}{l}\text { - Analysis of the dynamic in terms of inventory costs and } \\
\text { performance criteria such as rise time and overshoot. } \\
\text { - Influence of return rate on the dynamics of the SC. }\end{array}$ & Selected \\
\hline $\begin{array}{l}{[37]} \\
\text { Journal }\end{array}$ & $\begin{array}{l}\text { Zhao et al. } \\
2005\end{array}$ & Control Theory & $\mathrm{x}$ & & & $\begin{array}{l}\text { - Influence of the remanufacturing activity and the discrepancy of } \\
\text { lead-times on the order variance and inventory related costs. }\end{array}$ & $\begin{array}{l}\text { - Lack of specific insights on the influence of } \\
\text { reverse logistics factors on dynamic behaviour }\end{array}$ \\
\hline$[38]$ & $\begin{array}{l}\text { Tang and Naim } \\
2004\end{array}$ & $\begin{array}{l}\text { Control Theory \& } \\
\text { System Dynamics } \\
\text { Simulation }\end{array}$ & $\mathrm{x}$ & $\mathrm{X}$ & $\mathrm{x}$ & $\begin{array}{l}\text { - Application of the APIOBPCS to remanufacturing process based on } \\
\text { PUSH policy. } \\
\text { - Impact of information transparency on the performance of hybrid } \\
\text { systems. }\end{array}$ & Selected \\
\hline $\begin{array}{l}{[39]} \\
\text { Journal }\end{array}$ & $\begin{array}{l}\text { Zhou et al. } \\
2004\end{array}$ & Control Theory & $\mathrm{x}$ & & & $\begin{array}{l}\text { - Application of the APIOBPCS model to CLSC } \\
\text { - Insights on the smoothing of demand fluctuations generated by } \\
\text { higher return rate }\end{array}$ & - Extended version: article 34 \\
\hline $\begin{array}{l}{[40]} \\
\text { Journal }\end{array}$ & $\begin{array}{l}\text { Kumar et al. } \\
1994\end{array}$ & $\begin{array}{l}\text { System Dynamics } \\
\text { Simulation \& } \\
\text { Physical System } \\
\text { Theory }\end{array}$ & $\mathrm{x}$ & $\mathrm{x}$ & & $\begin{array}{l}\text { - Analysis of a repair inventory system based on the concept of unit } \\
\text { exchange spares } \\
\text { - Formalization of a Decision Support System (DSS) for different } \\
\text { decision policies in CLSC. }\end{array}$ & $\begin{array}{l}\text { - Lack of specific insights on the influence of } \\
\text { reverse logistics factors on dynamic behaviour }\end{array}$ \\
\hline
\end{tabular}

In the following, we report the five exclusion criteria (EC) used in this review and related excluded articles:

- EC \#1: Lack of specific insights. Articles [4], [6-7], [9], [13], [15], [17], [24], [26], [28-32], [37] and [40] are excluded from further analysis due to lack of "insights" on the potential impact of return flows factors on the dynamics of the CLSC.

- EC \#2: Extended Versions: Short communication article [35] and [39] are excluded as the related extended and comprehensive versions have been successively published in high quality international journals.

- EC \#3: Replicated Researches. Articles [18], [22], [24], [26], [29], [31] are excluded as they report analogous research as in [25]. In this fashion it is not possible to find additional contribution or new conclusions. 
- EC \#4: Pink Elephant. Articles [12] and [21] merely present the search string's terms in the keywords or abstract. However, they do not provide any insight on the dynamics of CLSC.

- EC \#5. Chinese dissemination. Articles [14] and [23] are excluded as they are formalized in Chinese language.

Finally, we select 13 articles specifically focusing on dynamics analysis in CLSC. These studies provide insights on the impact of two specific parameters of the reverse logistics structure:

1. The return rate: the percentage of products sold to the market, still renewable and collected in order to be recycled to become almost "as good as new".

2. The remanufacturing lead-time: the lead-time related to the process of recycling the collected products before being available again into the manufacturer's inventory.

\subsection{Step 4: Analysis and synthesis}

The aim of the fourth step is to break down individual studies into constituent parts and describe how each relates to the other (Denyer and Tranfield, 2009). To this end, the 12 selected articles are categorized according to the following criteria: methodology, number of SC echelons, return flow in the replenishment rule, consumer demand, inventory's and order's condition, impact of return rate and remanufacturing lead time on CLSC dynamics.

Table 2-CLSC and Bullwhip effect

\begin{tabular}{|c|c|c|c|c|c|c|c|c|c|c|}
\hline \multirow[t]{2}{*}{ Authors } & \multirow[t]{2}{*}{ Methodology } & \multirow{2}{*}{$\begin{array}{c}\text { SC } \\
\text { Config. }\end{array}$} & \multirow{2}{*}{$\begin{array}{l}\text { Return Flow } \\
\text { considered in the } \\
\text { Order Policy }\end{array}$} & \multirow{2}{*}{$\begin{array}{l}\text { Inventory } \\
\text { Condition }\end{array}$} & \multirow{2}{*}{$\begin{array}{c}\text { Consumer } \\
\text { demand }\end{array}$} & \multirow{2}{*}{$\begin{array}{c}\text { Order } \\
\text { Condition }\end{array}$} & \multicolumn{2}{|c|}{ Increasing "return rate" } & \multicolumn{2}{|c|}{$\begin{array}{c}\text { Increasing } \\
\text { "Remanufacturing Lead } \\
\text { Time" }\end{array}$} \\
\hline & & & & & & & Bullwhip & $\begin{array}{l}\text { Inventory } \\
\text { variance }\end{array}$ & Bullwhip & $\begin{array}{c}\text { Inventory } \\
\text { variance }\end{array}$ \\
\hline $\begin{array}{c}\text { Zhou and } \\
\text { Disney (2006) }\end{array}$ & Control Theory & $\mathrm{K}=1$ & Yes & $\begin{array}{l}\text { Negative } \\
\text { Allowed }\end{array}$ & i.i.d. & $\begin{array}{l}\text { Negative } \\
\text { Allowed }\end{array}$ & $\downarrow$ & $\downarrow$ & $\uparrow$ & $\uparrow$ \\
\hline $\begin{array}{l}\text { Tang and Naim } \\
\text { (2004) }\end{array}$ & $\begin{array}{c}\text { Control Theory \& } \\
\text { Difference equation } \\
\text { modelling }\end{array}$ & $\mathrm{K}=1$ & $\begin{array}{l}\text { Type 1: Yes } \\
\text { Type 2: Yes } \\
\text { Type } 3: \text { Yes }\end{array}$ & $\begin{array}{l}\text { Negative } \\
\text { Allowed }\end{array}$ & $\begin{array}{l}\text { Step for } \\
\text { Inventory } \\
\text { i.i.d. for } \\
\text { Bullwhip }\end{array}$ & $\begin{array}{l}\text { Negative } \\
\text { Allowed }\end{array}$ & $\begin{array}{l}\downarrow \text { Type } 1 \\
\downarrow \text { Type } 2 \\
\downarrow \text { Type } 3\end{array}$ & $\begin{array}{l}\uparrow \text { Type } 1 \\
\uparrow \text { Type } 2 \\
\downarrow \text { Type } 3\end{array}$ & $\uparrow$ & $\begin{array}{c}\uparrow \text { Type } 1 \\
--- \text { Type } 2 \\
\downarrow \text { Type } 3\end{array}$ \\
\hline $\begin{array}{l}\text { Adenso-Dìaz et } \\
\text { al. (2012) }\end{array}$ & Agent-based simulation & $\mathrm{K}=4$ & No & N.A. & i.i.d. & N.A. & $\approx$ & N.A. & N.A & N.A. \\
\hline $\begin{array}{l}\text { Turrisi et al. } \\
\text { (2012) }\end{array}$ & $\begin{array}{l}\text { Difference equation } \\
\text { modelling }\end{array}$ & $\mathrm{K}=1$ & Yes & $\begin{array}{l}\text { Backlog Not } \\
\text { Allowed }\end{array}$ & i.i.d. & $\begin{array}{l}\text { Negative } \\
\text { Not } \\
\text { Allowed }\end{array}$ & $\downarrow$ & $\approx$ & $\downarrow$ & $\uparrow$ \\
\hline $\begin{array}{l}\text { Huang and Liu } \\
\text { (2008) }\end{array}$ & $\begin{array}{l}\text { Difference equation } \\
\text { modelling }\end{array}$ & $\mathrm{K}=3$ & No & N.A. & Sin Wave & N.A. & --- & N.A. & $\uparrow$ & $\approx$ \\
\hline $\begin{array}{l}\text { Ding and Gan } \\
\quad(2009)\end{array}$ & $\begin{array}{l}\text { Difference equation } \\
\text { modelling }\end{array}$ & $\mathrm{K}=1$ & No & N.A. & Step & $\begin{array}{l}\text { Negative } \\
\text { Allowed }\end{array}$ & $\uparrow$ & N.A. & N.A. & N.A. \\
\hline $\begin{array}{l}\text { Wang \& Ding } \\
\quad \text { (2009) }\end{array}$ & $\begin{array}{l}\text { Difference equation } \\
\text { modelling }\end{array}$ & $\mathrm{K}=1$ & Yes & N.A. & Step & $\begin{array}{l}\text { Negative } \\
\text { Allowed }\end{array}$ & $\downarrow$ & N.A. & N.A. & N.A. \\
\hline $\begin{array}{l}\text { Qingli et al. } \\
\text { (2008) }\end{array}$ & $\begin{array}{l}\text { Difference equation } \\
\text { modelling }\end{array}$ & $\mathrm{K}=3$ & Yes & N.A. & i.i.d. & $\begin{array}{l}\text { Negative } \\
\text { Allowed }\end{array}$ & $\downarrow$ & $\uparrow$ & N.A. & N.A. \\
\hline $\begin{array}{l}\text { Zanoni et al. } \\
\text { (2006) }\end{array}$ & $\begin{array}{l}\text { Discrete-event } \\
\text { Simulation }\end{array}$ & $\mathrm{K}=1$ & Yes & $\begin{array}{l}\text { Backlog } \\
\text { Allowed }\end{array}$ & i.i.d. & N.A. & $\approx$ & N.A. & $\approx$ & N.A. \\
\hline $\begin{array}{l}\text { Pati et al. } \\
\text { (2010) }\end{array}$ & Statistical Analysis & $\mathrm{K}=6$ & Yes & $\begin{array}{l}\text { Negative } \\
\text { Allowed }\end{array}$ & AR Demand & $\begin{array}{l}\text { Negative } \\
\text { Allowed }\end{array}$ & $\downarrow$ & N.A. & N.A. & N.A. \\
\hline $\begin{array}{l}\text { Das and Dutta } \\
\quad \text { (2012) }\end{array}$ & $\begin{array}{l}\text { Difference equation } \\
\text { modelling }\end{array}$ & $\mathrm{K}=3$ & Yes & $\begin{array}{c}\text { Backlog Not } \\
\text { Allowed }\end{array}$ & $\begin{array}{l}\text { Random } \\
\text { Triangular } \\
\text { Fuzzy }\end{array}$ & N.A. & N.A. & N.A. & N.A. & N.A. \\
\hline $\begin{array}{l}\text { Corus et al. } \\
\text { (2014) }\end{array}$ & $\begin{array}{l}\text { Discrete-event } \\
\text { Simulation }\end{array}$ & $\mathrm{K}=1$ & Yes & $\begin{array}{l}\text { Backlog Not } \\
\text { Allowed }\end{array}$ & Poisson & N.A. & $\downarrow$ & N.A. & $\approx$ & N.A. \\
\hline
\end{tabular}




\begin{tabular}{|c|c|c|c|c|c|c|c|c|c|c|}
\hline $\begin{array}{l}\text { Zhou et al. } \\
\text { (2005) }\end{array}$ & $\begin{array}{l}\text { Control Theory \& } \\
\text { Difference equation } \\
\text { modelling }\end{array}$ & $\mathrm{K}=1$ & Yes & $\begin{array}{l}\text { Negative } \\
\text { Allowed }\end{array}$ & i.i.d. & $\begin{array}{l}\text { Negative } \\
\text { Allowed }\end{array}$ & $\downarrow$ & $\downarrow$ & N.A. & N.A. \\
\hline
\end{tabular}

\subsection{Step 5: Reporting and using the results}

The fifth and last step aims at identifying the research objectives arising from the literature gaps. From Table 2 we make the following conclusions, useful to establish the goal of our research.

- Majority of studies shows that a higher return rate implies a lower bullwhip effect. This finding is valid for both single and multi-echelon SCs, regardless the modelling assumptions and the methodological approach adopted by these studied. An opposite result has been found only by Ding and Gan et al. (2009). On the contrary, in terms of inventory instability, studies report considerable contrasting results. While Zhou et al. (2005) and Zhou and Disney (2006) show that inventory stability improves as the percentage of recollected product increases, Qingli et al. (2008) note an opposite trend. A peculiar exception is presented in the work of Tang and Naim (2004), in which, depending on the type of replenishment rules, inventory may have very different performances.

- The effect of remanufacturing lead-time on performance has not received particular attention, both in terms of bullwhip and inventory variance ratio. Furthermore, the few related studies show significantly contrasting results.

- It is very difficult to compare the results from different researches, because the analysed studies differ in terms of assumptions, parameters, and research methodology: i.e., number of echelons of the $\mathrm{SC}$, available information about the return flow used to calculate the replenishment quantity, final consumer's demand pattern, assumptions regarding the modelling of inventory' and order's quantity. (e.g. whether negative orders and inventory are allowed or not in the model).

As a summary, it seems that there is not consensus among researchers about the nature of the relationships between reverse logistics factors (e.g. product return rate, manufacturing lead time, etc.) and CLSC performance. We argue that this is mainly due to the fact that existing studies assess such relationships under very different conditions and scenarios. The conclusion is that managerial decisions on designing and managing CLSC's reverse logistics in order to improve performance should be contingent to a number of different factors (e.g. number of echelons of the SC, customer demand patterns, etc.).

In line with the above conclusion, this paper intends to contribution to the stream of literature studying CLSC dynamic issues. More specifically, we analyse how reverse logistics factors influence CLSC performance under different scenarios. In particular, we evaluate the impact of the return rate and the remanufacturing leadtime on both bullwhip effect and the inventory variance under different number of echelons in the SC, different amount of available information on the return flow of recycled products used in the replenishment rule, and different consumer's demand pattern. 


\section{METHODOLOGICAL APPROACH AND MODEL VALIDATION}

We adopt the System Dynamics modelling approach, advocated by Forrester (1961) as a method to investigate the dynamic effects in large non-linear systems. System Dynamics (SD) modelling plays a crucial role in advancing knowledge SC management, where mathematical modelling cannot accommodate the associated dynamic complexity (Syntetos et al. 2011). Furthermore, System Dynamics together with Control Theory represent the most adopted methodologies for the analysis of CLSC dynamics. To verify our model we reproduce the same experiments of Zhou \& Disney (2006) and Tang \& Naim (2004), which surely can be considered among the most cited studies in the stream of CLSC dynamics.

\subsection{Model verification - Zhou and Disney (2006)}

Zhou and Disney (2006) study a simple mono-echelon traditional structure with return of products in which the manufacturer adopts a modification of a smoothing order policy, i.e., APIOBPCS (John et al. 1994). For further information on this type of order rule see Lalwani et al. (2006), Disney and Lambrecht (2008), Cannella et al. (2011), among others. In their model, the return flow of "Remanufactured products" is directly pushed into the serviceable inventory. The order quantity is computed as follow:

$$
\text { ORDER }=\text { demand }+\left[\frac{(\text { Desired Inventory-Actual Inventory })}{\mathrm{Ti}}+\frac{(\text { Desired WIP-Actual WIP) }}{\mathrm{Tw}}\right]
$$

where $T_{i}$ and $T_{w}$ are the times to adjust serviceable inventory and WIP, respectively. Table 3 shows a qualitative comparison between our System Dynamics Simulation results and the output provided by Zhou \& Disney (2006). Both experiments present very similar trends when varying the numerical value of parameters and the difference in results is not significant.

Table 3 - Model verification: Zhou and Disney (2006)

\begin{tabular}{|c|c|c|c|c|c|c|c|c|}
\hline \multirow{3}{*}{$\mathbf{T i}$} & \multirow{3}{*}{ Tw } & \multirow{3}{*}{$\mathbf{T p}$} & \multirow{3}{*}{ Tr } & \multirow{3}{*}{$\mathbf{k}$} & Zhou \& Disney (2006) & $\begin{array}{c}\text { System } \\
\text { Dynamics } \\
\text { Simulation }\end{array}$ & \multirow{2}{*}{$\begin{array}{c}\text { Zhou \& Disney (2006) } \\
\text { Normal Distribution (i.i.d.) }\end{array}$} & \multirow{2}{*}{$\begin{array}{c}\text { System Dynamics } \\
\text { Simulation } \\
\text { D } \sim \mathrm{N}\left(0.5^{2}\right)\end{array}$} \\
\hline & & & & & Normal Distribution (i.i.d.) & $\mathrm{D} \sim \mathrm{N}\left(0.5^{2}\right)$ & & \\
\hline & & & & & \multicolumn{2}{|c|}{$\begin{array}{c}\text { Average Values } \\
\text { (Inventory Variance) }\end{array}$} & \multicolumn{2}{|c|}{$\begin{array}{l}\text { Standardized Values } \\
\text { (Inventory Variance) }\end{array}$} \\
\hline 4 & 4 & 8 & 4 & 0.3 & 4.55 & 4.91 & -0.92 & -0.88 \\
\hline 4 & 8 & 8 & 4 & 0.3 & 4.05 & 4.42 & -1.07 & -1.03 \\
\hline 8 & 8 & 8 & 8 & 0.3 & 6.81 & 7.10 & -0.20 & -0.23 \\
\hline 8 & 16 & 16 & 8 & 0.6 & 5.65 & 5.79 & -0.57 & -0.62 \\
\hline 16 & 16 & 16 & 32 & 0.6 & 12.25 & 13.00 & 1.53 & 1.54 \\
\hline 16 & 32 & 16 & 32 & 0.6 & 12.19 & 12.94 & 1.51 & 1.52 \\
\hline 32 & 32 & 4 & 16 & 0.9 & 6.85 & 7.13 & -0.19 & -0.22 \\
\hline 32 & 4 & 4 & 16 & 0.9 & 7.14 & 7.62 & -0.09 & -0.07 \\
\hline
\end{tabular}

\subsection{Model verification - Tang and Naim (2004)}

Tang and Naim (2004) study the effect of three types of order-up-to policy on the bullwhip effect. The proposed three rules differ in the degree of information transparency across the SC, specifically in how 
information about the flow of remanufactured products and/or the remanufacturing lead time is transmitted by downstream collaborative partners and embedded in the order policy. Type 1 is almost identical to the rule studied by Zhou and Disney (2006). Types 2 and 3 are characterized by an increasing level of information transparency.

In our verification experiment, we reproduce the Type 3 system, i.e., the policy characterized by the highest level of information transparency. In this case, the manufacturer has access to updated information on the percentage of re-collected products and on the remanufacturing lead time, and exploits this information for the computation of the order. In fact, as stated by the authors "we consider WIP both in the manufacturing and remanufacturing processes. This system makes best use of information from the remanufacturing process in the manufacturing processes control structure" (Tang and Naim 2004, pp. 4140).

The order quantity is computed as follow:

$$
\text { ORDER }=\text { demand }+\left[\frac{(\text { Desired Inventory-Actual Inventory })}{\mathrm{Ti}}+\frac{(\text { Desired WIP-Actual WIP })}{\mathrm{Tw}}\right] \text {-Remanufactured Products }
$$

In Figure 1 the results provided by Tang and Naim (2014) in terms of Inventory, WIP and Throughput (COMRATE) and our output, under the same boundary condition, are compared.

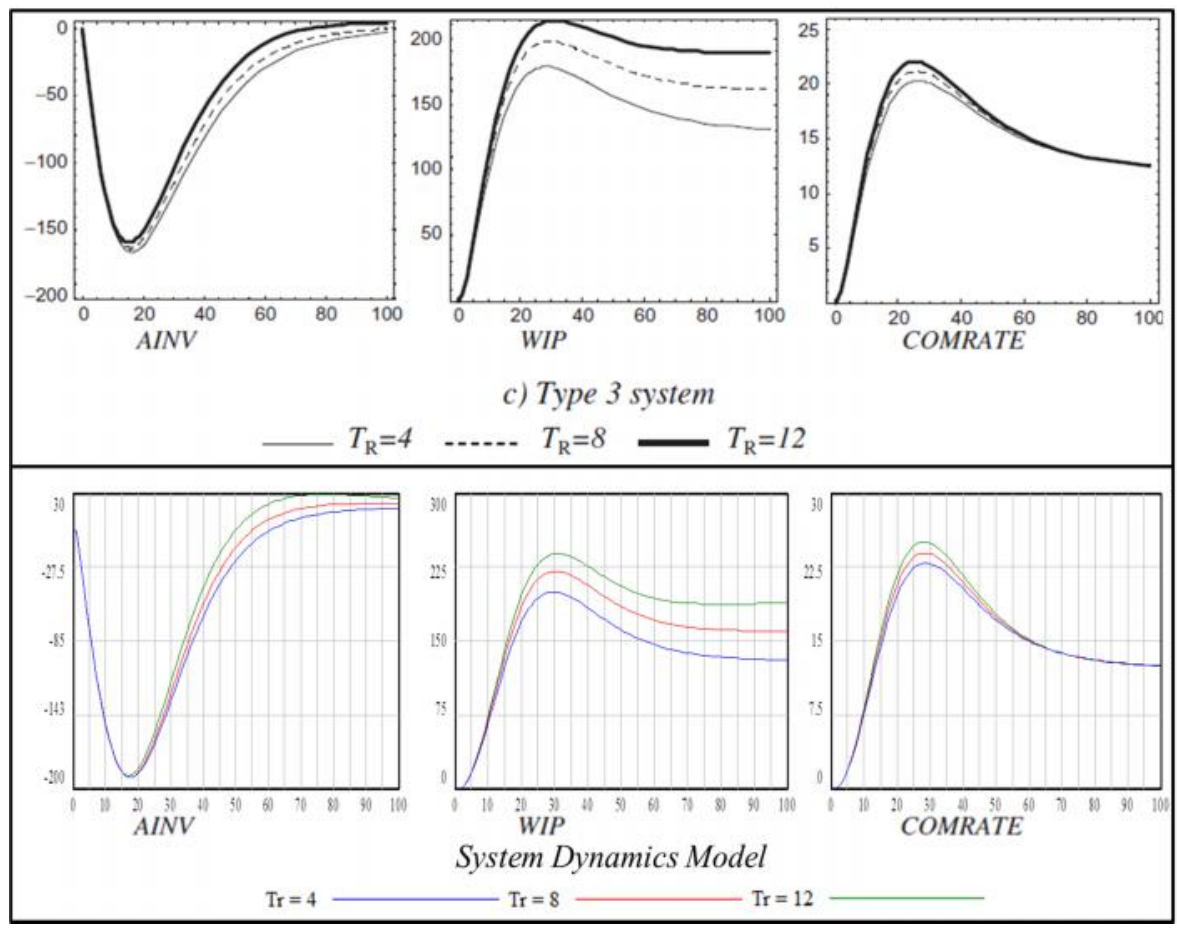

Figure 1. Model verification - Tang \& Naim (2004)

Similarly to the previous test, by reproducing the experiment of Tang \& Naim (2004), we obtain an identical $\mathrm{SC}$ behaviour. This represents a relevant insight, as it allows us to conduct our analyses by using a simulation model which is validated with two well-known CLSC models in this field. 


\section{CLSC MODEL}

In this section we present assumptions and the mathematical formalization of the studied CLSC model. The following assumptions characterize our model:

- Single-product, $K$-stage production-distribution serial system. Each echelon in the system has a single successor and a single predecessor. The generic echelon's position is represented by index $i$. Echelon $i=1$ stands for the manufacturer and $i=K+1$ for the final customer.

- Only a percentage $0 \leq a \leq 1$ of market sales can be collected in the reverse loop; the remaining $1-a$ quantity is hypothesized to be unusable or disposed to a landfill. An important element of the remanufacturing loop is the time lag existing between the sale of products and their remanufacturing. Before products become available for recycling, in fact, they are hold by customers for a time known as "consumption lead-time" or "time for the customer to keep the product". Once the fraction of products is collected, the remanufacturer spends time for the recovery process. This time is known as remanufacturing lead time.

- We adopt the two previously discussed replenishment order policies, i.e., Zhou and Disney (2006) and Tang and Naim (2004). In this manner, we are reproducing the CLSC under two different degree of information transparency.

- We use the Simple Exponential Smoothing as forecast technique for incoming orders. According to Disney and Lambrecht (2008) this technique has been selected as it is well understood and popular with practitioners.

- We implement the non-negative condition of order quantity. Products delivered cannot be returned to the supplier. By adopting this assumption, we implement a more reliable modelling assumption for the bullwhip effect analysis. In fact, as recently shown by (Chatfield and Pritchard 2013, and Dominguez et al. 2015) models that allow product returns may result in an overestimation of the bullwhip effect.

- Production-distribution capacity is unconstrained. No quantity limitations in production, buffering and transport are considered. Backlogging is not allowed. Therefore, orders not fulfilled in time convert into lost sales.

The mathematical nomenclature is reported in Table 3. The full model is reported in Table 4.

Table 3 - Model nomenclature

\begin{tabular}{llll}
\hline \multicolumn{2}{l}{ VARIABLES } & \\
$B$ & Orders backlog & $I$ & Inventory \\
$C$ & Collected products & $W$ & Work in progress \\
$d$ & Market demand & $O$ & Replenishment order quantity \\
$\hat{d}$ & Market demand forecast & $T I$ & Target work in progress
\end{tabular}




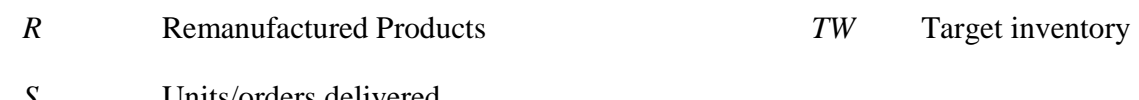

$S \quad$ Units/orders delivered

\section{PARAMETERS}

$\begin{array}{llll}\alpha & \text { Forecast smoothing factor } & T & \text { Time horizon } \\ T r & \text { Remanufacturing lead time } & T_{c} & \text { Consumption lead-time } \\ T m & \text { Manufacturing/distribution lead time } & T_{p} & \text { Estimated pipeline time } \\ i & \text { Echelon's position in the SC } & T_{w} & \text { Wip proportional controller } \\ a & \text { Return rate of collected products } & T_{i} & \text { Inventory proportional controller } \\ \mathrm{K} & \text { Total number of echelons } & & \end{array}$

\section{STATISTICS}

\begin{tabular}{|c|c|c|c|}
\hline$\sigma_{d}^{2}$ & Variance of the market demand & $\sigma_{o}^{2}$ & Variance of the order quantity \\
\hline$\sigma_{I}^{2}$ & Variance of the inventory & $\mu_{d}$ & Steady state market demand \\
\hline
\end{tabular}

Table 2 - CLSC mathematical model

\begin{tabular}{|c|c|c|}
\hline Zhou and Disney policy & $O_{i}(t)=\hat{d}_{i}(t)+\frac{1}{T_{w_{i}}}\left(T W_{i}(t)-W_{i}(t)\right)+\frac{1}{T i_{i}}\left(T I_{i}(t)-I_{i}(t)\right)$ & (1) \\
\hline Tang and Naim policy & $O_{i}(t)=\hat{d}_{K}(t)+\frac{1}{T_{w_{i}}}\left(T W_{i}(t)-W_{i}(t)\right)+\frac{1}{T i_{i}}\left(T I_{i}(t)-I_{i}(t)\right)-R_{1}(t)$ & (1) \\
\hline $\begin{array}{l}\text { Work in progress for } \\
\text { Zhou's and Disney's policy }\end{array}$ & \multicolumn{2}{|l|}{$W_{i}(t)=W_{i}(t-1)+S_{i-1}(t)-S_{i-1}(t-T m)$} \\
\hline $\begin{array}{l}\text { Work in progress for } \\
\text { Tang and Naim policy }\end{array}$ & $I_{i}(t)=\left\{\begin{array}{l}W_{i}(t-1)+S_{i-1}(t)+C_{1}(t)-R_{1}(t)-S_{i-1}(t-T m) \\
W_{i}(t-1)+S_{i-1}(t)-S_{i-1}(t-T m) \quad \forall i=1\end{array}\right.$ & (3) \\
\hline Inventory & $I_{i}(t)=\left\{\begin{array}{l}I_{i}(t-1)+S_{i-1}(t-T m)+R_{1}(t)-S_{1}(t) \\
I_{i}(t-1)+S_{i-1}(t-T m)-S_{i}(t) \quad \forall i \neq 1\end{array}\right.$ & (4) \\
\hline Target Work in Progress & $T W_{i}(t)= \begin{cases}T p \cdot \hat{d}_{i}(t) & \forall i=1 \\
T m \cdot \hat{d}_{i}(t) & \forall i \neq 1\end{cases}$ & (5) \\
\hline Target Inventory & $T I_{i}(t)=\hat{d}_{i}(t)$ & (6) \\
\hline \multirow{2}{*}{ Demand forecast } & $\hat{d}_{i}(t)=\alpha O_{i+1}(t-1)+(1-\alpha) \hat{d}_{i}(t-1)$ & (7) \\
\hline & $O_{K+1}(t)=d(t)$ & $(8)$ \\
\hline Orders finally delivered & $S_{i}(t)=\min \left\{O_{i+1}(t) ; I_{i}(t-1)\right\}$ & (9) \\
\hline $\begin{array}{l}\text { Non-negativity condition } \\
\text { of order quantity }\end{array}$ & $O_{i}(t) \geq 0$ & $(10)$ \\
\hline $\begin{array}{l}\text { Uncapacitated raw material } \\
\text { supply condition }\end{array}$ & $S_{i-1}(t)=O_{1}(t) ; \quad i=1$ & (11) \\
\hline Collected Products & $C_{1}(t)=a \cdot S_{k}\left(t-T_{c}\right)$ & $(12)$ \\
\hline Remanufactured Products & $R_{1}(t)=C_{1}\left(t-T_{r}\right)$ & (13) \\
\hline
\end{tabular}




\section{EXPERIMENTAL DESIGN AND NUMERICAL RESULTS}

To achieve the research objectives, we adopt the design of experiment (DOE) approach. DOE investigates which factors influence the performance of the SC. We analyse the following 4 factors:

- F1. Return rate $a$. Due to the several contrasting statements about the impact of such factor on the two metrics (Zhou \& Disney 2006, Turrisi et al. 2013, Huang and Liu 2008, Qingli et al. 2008) including a non-linear behaviour of the bullwhip effect (Adenso-Dìaz et al. 2012), we adopt three levels, i.e., 0\%, $40 \%, 70 \%$. The first level allows us to also compare a CLSC with a traditional one.

- $\quad$ F2. Remanufacturing lead-time $T_{r}$. Even for this factor we choose three levels. i.e., 1, 4, 7.

- F3. Number of echelons $K$. A recent study (Chatfield 2013) suggests that decomposition of a multi-stage SC into a set of two-stage models systematically underestimates the bullwhip effect. Given these consideration we set two levels for this factor: 1, 3 (echelons). With reference to the latter configuration we calculate both the metrics for the last echelon of the chain, i.e., the manufacturer.

- F4. Information transparency: By modelling and testing the response of the CLSC for Tang and Naim (2004) policy as well as for Zhou and Disney (2004) policy we may infer on the impact of information transparency in CLSC.

Table 5 reports the level values of the four factors studied.

\begin{tabular}{lll}
\multicolumn{2}{c}{ Table 5 - CLSC mathematical model } \\
\hline \multirow{2}{*}{$\mathrm{Tr}$} & Remanufacturing Lead-Time & 1 time unit \\
& & 4 time units \\
& & 7 time units \\
\hline & Return Rate & $0 \%$ \\
& & $40 \%$ \\
K-echelon & Number of echelons & $70 \%$ \\
\hline Policy & Degree of transparency information & 1 \\
& & 3 \\
\hline
\end{tabular}

Regarding other parameters, we set $T_{i}=T_{w}=T_{m}$ and $T_{a}=2 T_{m}$ as a compromise solution for the APIOBPCS rule (Tang and Naim, 2004). More specifically, we use the same values adopted by Tang and Naim (2004) for their simulations, i.e., $T_{i}=8, T_{w}=8, T_{m}=8, T_{a}=16, T_{c}=32$. Regarding the estimate pipeline lead time, we adopt the values proposed by these authors in order to avoid the inventory offset. Given the lack of information about this parameter in the work of Zhou and Disney (2006), and due to the similarities between their model and the Type 1 system of Tang and Naim (2004), we use their notation for the $T_{p}$ proposed for such system by the latter authors: $\mathrm{T}_{\mathrm{p} \text { (Zhou and Disney) }}=(1-\alpha) \mathrm{T}_{\mathrm{m}}-\alpha \mathrm{T}_{\mathrm{w}} ; \mathrm{T}_{\mathrm{p} \text { (Tang and Naim) }}=(1-\alpha) \mathrm{T}_{\mathrm{m}}+\alpha \mathrm{T}_{\mathrm{r}}$

The target inventory is computed by considering a safety factor $z=3.09$ (service level of 99.9\%) through the formalization proposed by Disney and Lambrecht (2008). 
Concerning the customer demand, we adopt the framework proposed by Towill et al. (2007) for studying the bullwhip effect. Basically, this framework suggests the typology of endogenous input that can be adopted in bullwhip analysis in order to study different characteristics of the SC. More specifically, we adopt two input demand patterns, i.e., the shock lens and the variance lens. The former aims at inferring on the performance of SCNs for a stationary input demand. The latter aims at inferring on the performance of SCNs for an unexpected and intense change in the end customer demand. This latter approach can be viewed as a "crash test' or a 'stress test': studying the system performance under an intense (Dominguez et al. 2014). In our case, attending to the variance lens perspective, we choose to set a stationary demand pattern to simulate a very stable system, i.e., $N \sim\left(100,10^{2}\right)$. Attending to the shock lens perspective, we use a $N \sim\left(100,10^{2}\right)$ distribution, which suffers an $100 \%$ average increase in the middle of the simulation time (see Fig. 2).

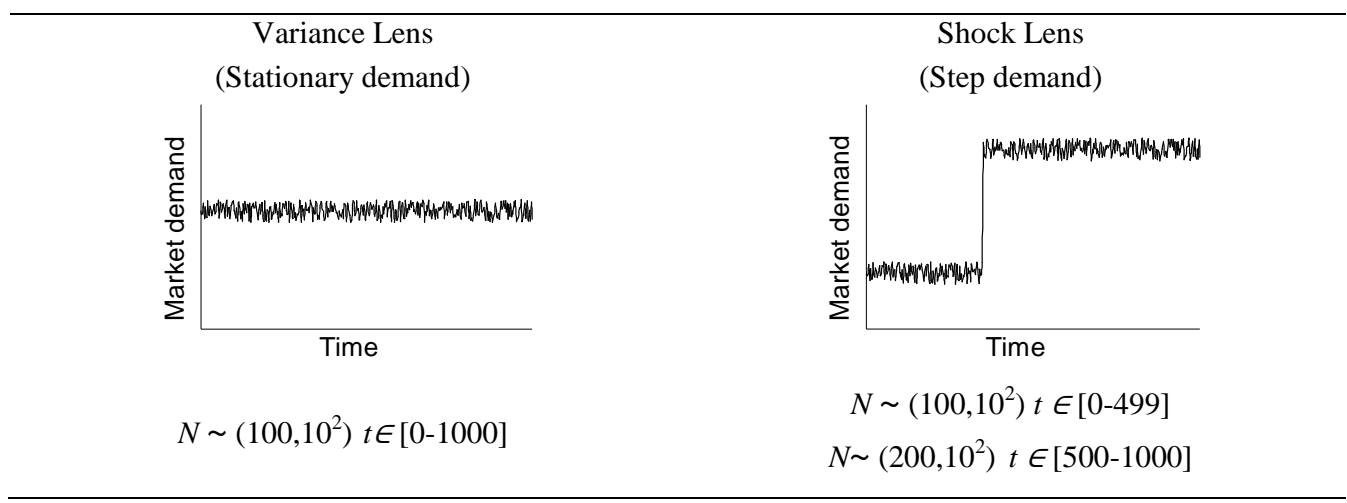

Figure 2. Demand patterns

As previously stated, CLSC performance is measured via a set of metrics, whose reduction reflects improved cost effectiveness of members' operations (Cannella and Ciancimino 2010), i.e., the Order Rate Variance Ratio (Eq. 14) proposed by Chen et al. (2000), the Inventory Variance Ratio (Eq. 15), proposed by Disney and Towill (2003).

Order Rate Variance Ratio ${ }_{i}=\frac{\sigma_{o_{i}}^{2} / \mu_{o_{i}}}{\sigma_{d}^{2} / \mu_{d}}$

Inventory Variance Ratio $_{i}=\frac{\sigma_{t_{i}}^{2} / \mu_{t_{i}}}{\sigma_{d}^{2} / \mu_{d}}$,

We design two sets of experiments: the stationary response set and the dynamic response set. Indeed, by separating them, we can concentrate our analysis on the four factors selected. The time length chosen is 700 periods, with the first 200 periods of each replication removed as a warm-up used to set-up the system. We 
replicated our $3^{2} \times 2^{2}=36$ treatments 10 times for a total of 360 simulations for each response set analysed. The statistical analysis is performed using Minitab statistical software with a level of significance $\mathrm{p}=0.05$. The following table shows the results of the analysis of variance (ANOVA) for both Inventory Variance Ratio (IVrA) and Order Rate Variance Ratio (OVrA), under a stationary set and under a step impulse of the demand, respectively.

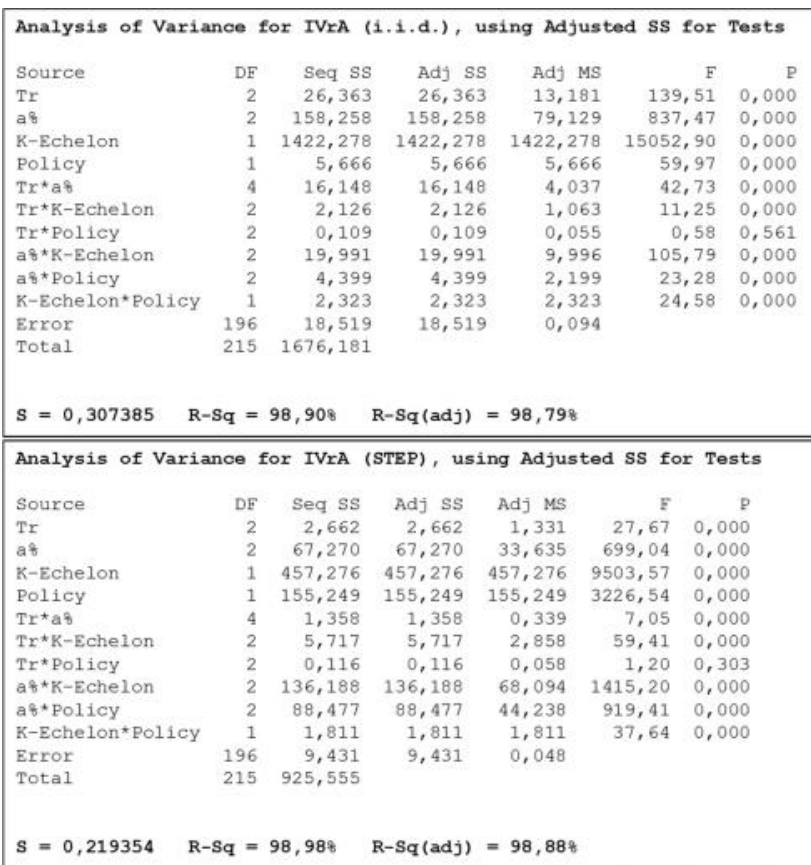

Figure 3. ANOVA results for IVrA and OVrA

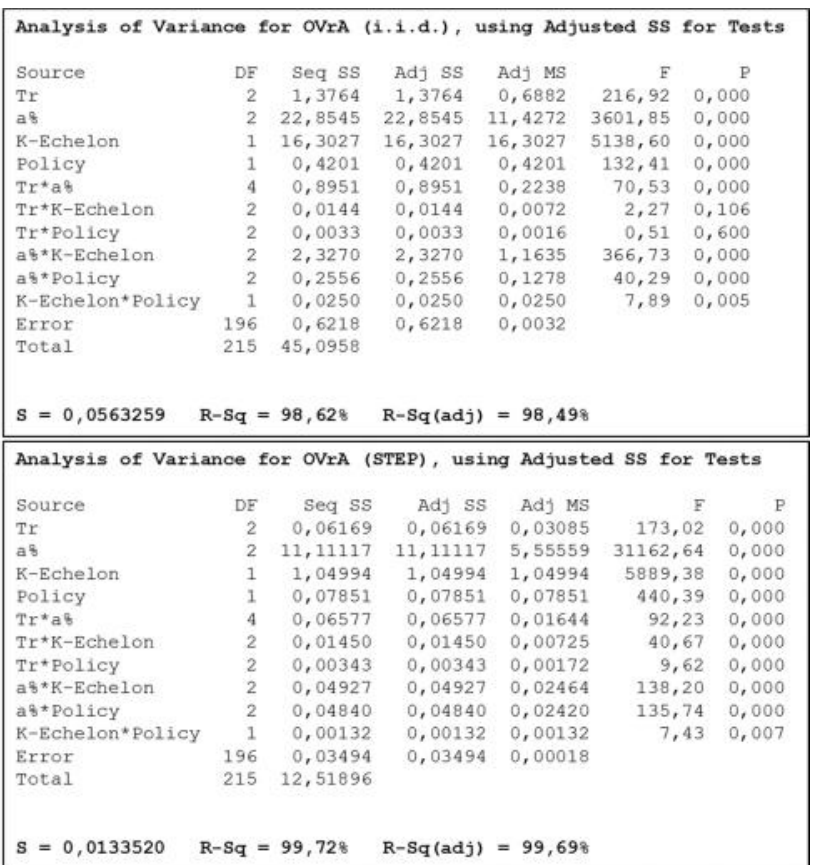

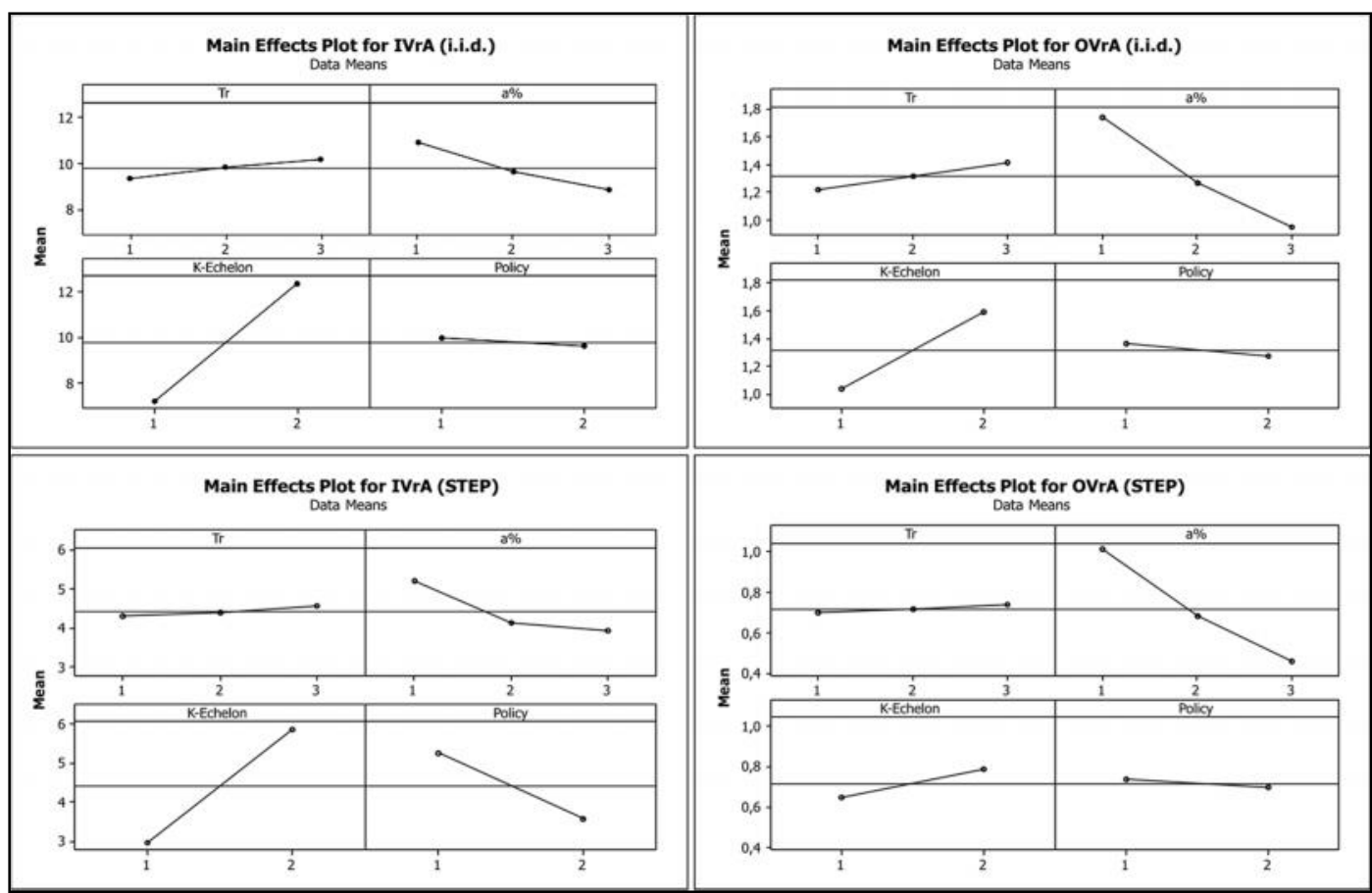

Figure 3. Main effect plot for IVrA and OVrA 


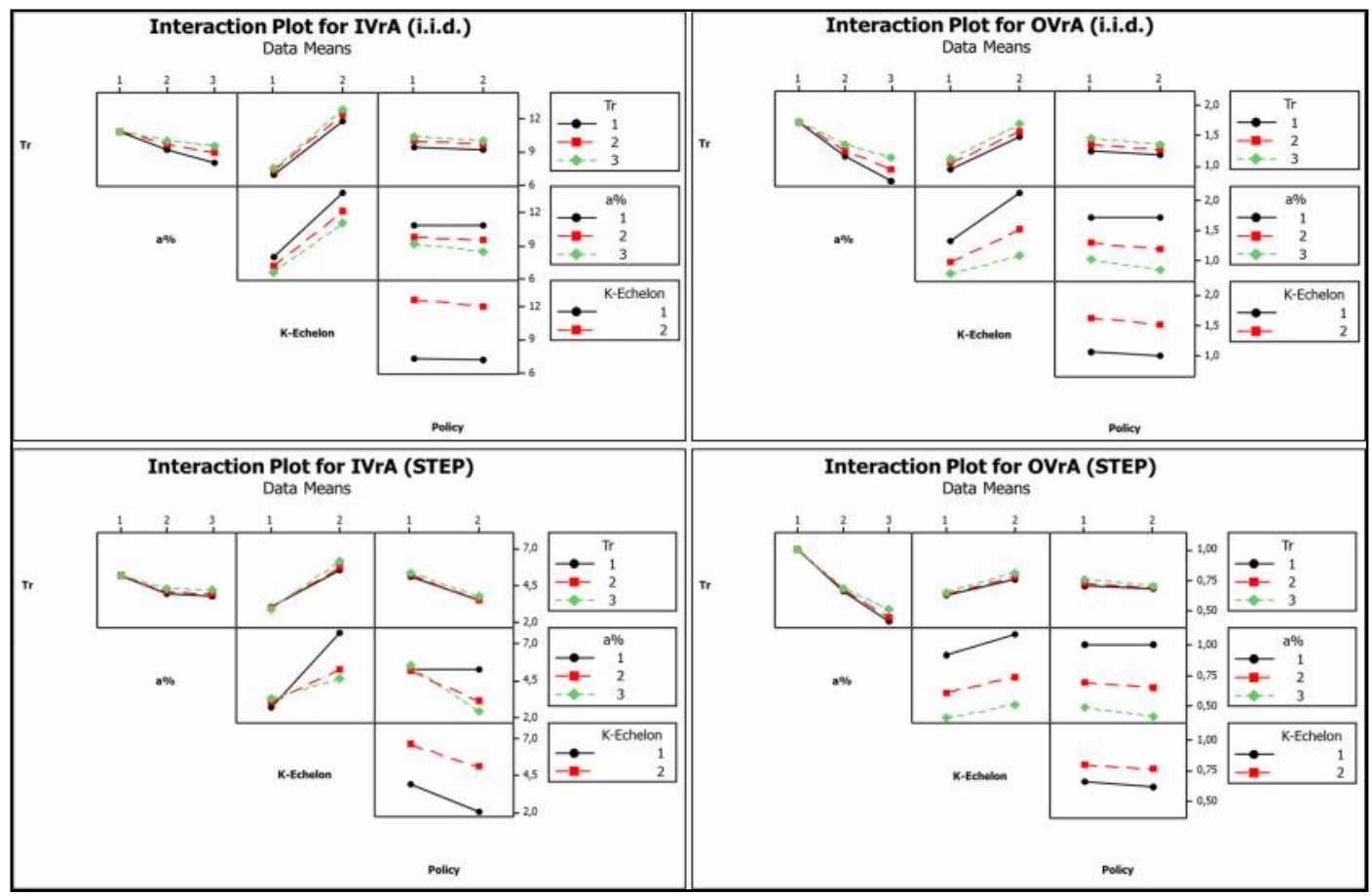

Figure 4. Interaction plot for IVrA and OVrA

\section{FINDINGS AND IMPLICATIONS}

The models developed and the subsequent experimental simulations have produced interesting findings which may contribute to the literature on this field and have implications for managerial practice.

In general terms, results show that all factors present a significant impact on bullwhip and inventory stability (Fig 3 and 4). More specifically, (1) as the percentage of recollected items increases, SC performance improves as well. Analogously, (2) as remanufacturing lead time increases, the SC dynamics degenerate. (3) Moreover, by shifting from a SC with a low level of information transparency to a SC whose information on recollected products is shared, the experiments show that bullwhip and inventory variability are strongly dampened. (4) Finally, as expected, the numbers of echelons exacerbate demand amplification phenomenon. All these trends are confirmed under both stationary and shock demand scenarios.

A further relevant finding can be derived by the identical trends of both bullwhip effect and inventory stability. Unlike other related previous works, in our study, if the Order Rate Variance Ratio increases/decreases under a variation of reverse logistics factors, the Inventory Variance Ratio increases/decreases as well.

In the following subsections, we describe the effect of each factor and report the corresponding managerial implications.

\subsection{Return Rate: from Traditional SC to CLSC}

Results show that the return flow positively impacts the CLSC performance. In fact, when shifting from the traditional SC $(a=0 \%)$ to the CLSC configurations ( $a=40 \%$ and $70 \%)$, the manufacturer experiences a considerable reduction both in bullwhip and inventory instability. Moreover, this reduction is obtained for both 
demand patters scenarios (i.e., stationary and shock). This finding supports SC studies affirming that bullwhip effect and inventory variance are lower in CLSC than in traditional SC (see Table 2), and contributes to the current scientific debate on what are the effects of the return flow of materials on the dynamics of the SC. Additionally, our analysis adds new knowledge regarding to the impact of the return flow magnitude. For all scenarios, as the percentage of return products increases, bullwhip effect and inventory instability decrease. Ceteris paribus, the CLSC with the highest return rate $(a=70 \%)$ reveals the most preferable dynamics. Finally, we note how the effect of the others logistic factors are significantly altered by the magnitude of recollected products. Interactions show that higher level of return rate increases the robustness of the CLSC, by dampening the negative effect of partially transparent information, high remanufacturing lead time, and high number of echelons.

Thanks to this findings we are able to suggest companies to invest in reverse logistics, try to increase the return of products, and implement ad hoc order management policies which take into account the reverse flow. In other words, managers have to promote reverse logistics not just in the name of the sustainabilityorientation of their firm, but also because returns flow improve the dynamics of the SC. The return flow, if supported and managed with ad-hoc order polices, increases the stability of the member's orders and, consequently, reduces the unnecessary costs associated to the demand and inventory variance amplification. We can conclude that the return flow acts as a bullwhip-limiting agent under different operational and market conditions. In fact, both mono and multi-echelon SCs benefit from adopting a CLSC configuration and this benefit increase when the magnitude of the returns flow increases. This conclusion has several implications for SC managers. For example, when the manufacturer experiences long supplier lead times because of geographical dispersion (which dramatically influences SC dynamics), investing in reverse logistics and developing commercial strategies to increase the percentage of return products becomes crucial to avoid poor SC performance.

\subsection{Remanufacturing Lead-Time: the persistence of Compression Principle}

Remanufacturing lead time impacts the dynamics of the CLSC. As this factor increases, both order and inventory stability decrease, particularly for the stationary demand scenario. Analysis of the interactions also provides further interesting results: as the percentage of recollected product increases, the negative effect of remanufacturing lead time on SC dynamics increases.

Manufacturing and distribution lead times are recognised among the operational variables that mostly impact the effectiveness of operations in the SC (Ciancimino et al. 2012, Li et al. 2014). Thus, lead-time reduction has been recognised as a direct driver for business improvement (Towill, 1996). In this work we show that the Time Compression Principle (Geary et al. 2006, Towill and Gosling 2014), advocated as a powerful strategy to limit the bullwhip effect, should be extended to remanufacturing lead time. Essentially, in order to improve CLSC dynamics, the manufacturer has to invest in recycling technology in order to reduce recycling process time. Furthermore, in order to really take advantage from the reverse flow of products, managers may focus on production and operations approaches devoted to make the remanufacturing process leaner, for instance by 
adopting lean and six sigma methodologies, and by turning to outsourcing strategies for faster logistics services.

\subsection{Transparency Information: Collaboration on recovery process}

In CLSC, higher information transparency may be achieved by shifting from Zhou and Disney order policy to Tang and Naim one. In fact, adopting the former is equivalent to merely considering information on the level of finished remanufacturer product. On the contrary, by adopting the latter policy, the manufacturer needs to receive up-to-date information on the percentage of recollected product from downstream members. Only in this way, the benefits of information visibility can be exploited. Results show how both demand and inventory oscillations decrease if the manufacturer adopts the Tang and Naim order rule with respect to the Zhou and Disney order rule. More specifically, this benefit is higher under a shock demand scenario.

This finding provides interesting insights on a rarely explored kind of information sharing in SC. In literature, collaboration and information visibility are generally included among the bullwhip avoidance strategies par excellence (Lee 2010). At the operational level, collaboration is concerned with the alignment of decision making among SC partners in their planning and inventory management. This alignment is enabled by the exchange of information in the SC (Stadtler 2009, Cannella 2014). However, most of the literature dealing with the benefit of collaborative practices usually refers to the sharing of information on customer demand, inventory levels, in-transit items and other operational factors. On the contrary, we argue that, in CLSCs, an effective SC collaboration practice may be achieved by sharing up-stream information on the levels of recollected items. In particular, results suggest that the visibility on the entire remanufacturing process may be crucial in a turbulence market environment (i.e., demand shock scenario), and increases CLSC's resilience . In this fashion, we reassert the empirical evidences shown by Dadhich et al. 2015): sharing information on returns rate will help to manage risks and integrate sustainable practices in business processes.

\subsection{Number of echelons: improving SC dynamics in turbulence scenarios}

Similarly to the traditional forward SC, the number of SC tiers in CLSC strongly influences both bullwhip and inventory variance. In all simulated scenarios, when the number of tiers increases the orders and inventory oscillations increase as well. In particular, the magnitude of this detrimental effect is more acute under the shock demand. Additionally, by looking at the interaction effects we get further interesting insights on this relationship. In the mono-echelon structure, the manufacturer experiences a performance improvement by shifting from a traditional SC ( $a=0 \%)$ to the CLSC configurations ( $a=40 \%$ and $70 \%)$. Analogously, in the multi-echelon SC, the manufacturer benefits from a reduction of order and inventory instability. However, the magnitude of this improvement is considerably higher with respect to the mono-echelon structure. A similar benefit is obtained by increasing the level of information transparency. These findings suggest that the detrimental effect of the SC's length (number of echelons) on the variability of orders and inventories can be moderated by combining a reverse logistics SC with ad-hoc order policies based on transparent information about the whole remanufactured process. 
These results lead to two interesting managerial implications. Firstly, as for the traditional SC, in CLSC, the "echelon elimination" principle (i.e., design the SC with the minimum number of echelons appropriate to the goals of the SC) (Geary et al. 2006) may be considered a bullwhip-limiting strategy. Secondly, in order to improve SC performance, if the removal of intermediate channels is not possible, the manufacturer should invest in increasing the flow of recollected products and adopt collaboration practices with the aim to share information on the remanufacturing process.

\section{CONCLUSION}

The purpose of this paper was to study the CLSC's dynamics and the effect of reverse logistics' factors on the order and inventory variance amplification. Firstly we performed a systematic literature review of the studies dealing with return flow and CLSC. By doing so we established the basis for a quantitative and robust analysis of CLSC. More specifically, we adopted a difference equation math approach, opportunely validated by comparing our model with two relevant studies of the bullwhip literature, namely Tang and Naim (2014) and Zhou and Disney (2006). Finally, we quantified the CLSC response to variations of its reverse logistics factors under different market conditions. In particular, we have adopted both the variance lens and the shock lens market conditions proposed by Towill et al. (2007).

The results of this research show that, ceteris paribus, order and inventory stability is a CLSC is higher than in a traditional forward SC for both mono-echelon and multi-echelon structures and under both stationary and turbulence market demands. Furthermore, as the product return rate increases, bullwhip effect and inventory instability decrease. In this regard, companies have to invest in returns management, not only to accept the advocated challenge of sustainable operations, but also because feeding the production-distribution system with product returns flow will improve the SC dynamic performance.

Another interesting finding of this study is that visibility of information on the entire remanufacturing cycle and the adoption of ad-hoc collaborative order policies may be crucial in a turbulence market environment. Analogously, the reduction of the remanufacturing lead time may represent a bullwhip-avoidance strategy for CLSCs. Finally, the number of SC tiers may alter the performance of the manufacturer. However, by conveniently augmenting and managing the return flow process, the manufacturer may smooth the variability transmitted by downstream echelons.

The main limitation of the present study relies on the fact that the results obtained depend on the modelling assumptions. In fact, our simulation experiments have been designed with fixed operational factors such as forecasting parameters, order rule proportional controllers, the production lead-time, and safety stock factors. We have made this simplification in order to focus only on the reverse logistics factors. However, our results should be confirmed also under different parameter's values settings. Furthermore, we have focused on a serial CLSC multi-echelon structure. The present study may be extended in different SC configurations, such as divergent SC. 
Another limitation arises from the analysis of the two policies that consider (even if in different way) the return flow in the calculation of the order quantity. It would be of interest to study policies ignoring the return flow and to propose novel replenishment rules to manage it.

Finally, in this work we have adopted well-established modelling assumptions and obtained theoretical distributions for data input (Evers and Wan 2012) to emulate the probabilistic nature of a CLSC, on the basis of other theoretical and what-if analyses. However, this work lacks of a grounded-empirical approach. Further work may employ a multimethod approach, using both empirical and simulated CLSC data to validate and deep our contribution.

\section{REFERENCES}

Adenso-Díaz, B., Moreno, P., Gutiérrez, E., Lozano, S. (2012). An analysis of the main factors affecting bullwhip in reverse supply chains. International Journal of Production Economics 135 (2), 917-928.

Ashayeri, J., Ma, N., Sotirov, R. (2015). The redesign of a warranty distribution network with recovery processes. Transportation Research Part E: Logistics and Transportation Review 77, 184-197.

Brandenburg, M., Govindan, K., Sarkis, J., Seuring, S. (2013). Quantitative models for sustainable supply chain management: Developments and directions. European Journal of Operational Research 233 (2), 299-312.

Cannella S. (2014) Order-up-to policies in information exchange supply chains. Applied Mathematical Modelling 38 (21), $5553-5561$.

Cannella S., Barbosa-Povoa A.P., Framinan J.M., Relvas S. (2013). Metrics for bullwhip effect analysis. Journal of the Operational Research Society 64 (1), 1-16.

Cannella, S., Ciancimino, E. (2010). On the Bullwhip Avoidance Phase: supply chain collaboration and order smoothing. International Journal of Production Research 48 (22), 38.

Cannella, S., Ciancimino, E., Framinan, J.M., (2011). Inventory policies and information sharing in multi-echelon supply chains. Production Planning \& Control, 22 (7), 649-659.

Carter, C. R., Rogers, D. S. (2008). A framework of sustainable supply chain management: moving toward new theory. International journal of physical distribution \& logistics management, 38 (5), 360-387.

Chatfield, D. C., Kim, J. G., Harrison, T. P. Hayya, J. C. (2004). The Bullwhip Effect-Impact of Stochastic Lead Time, Information Quality, and Information Sharing: A Simulation Study. Production and Operations Management, 13 (4), 340-353.

Chatfield, D. C., Pritchard, A. M. (2013). Returns and the bullwhip effect. Transportation Research Part E: Logistics and Transportation Review 49 (1), 159-175.

Chatfield, D. C. (2013). Underestimating the bullwhip effect: a simulation study of the decomposability assumption. International Journal of Production Research, 51 (1), 230-244.

Chen, F., Drezner, Z., Ryan, J., Simchi-Levi, D., (2000). Quantifying the Bullwhip Effect in a Simple Supply Chain: The Impact of Forecasting, Lead Times, and Information. Management Science, 46 (3), 436-443.

Coronado Mondragon, A. E., Lalwani, C., Coronado Mondragon, C. E. (2011). Measures for auditing performance and integration in closed-loop supply chains. Supply Chain Management: An International Journal, 16 (1), 43-56.

Corum, A., Vayvay, Ö., \& Bayraktar, E. (2014). The impact of remanufacturing on total inventory cost and order variance. Journal of Cleaner Production, 85, 442-452.

Dadhich, P., Genovese, A., Kumar, N., Acquaye, A. (2014). Developing sustainable supply chains in the UK construction industry: A case study. International Journal of Production Economics 164, 271-284. 
Das, D., Dutta, P. (2012). A Simulation Study of Bullwhip Effect in a Closed-Loop Supply Chain with Fuzzy Demand and Fuzzy Collection Rate under Possibility Constraints. Proceedings of World Academy of Science, Engineering and Technology, 10061013.

Das, D., Dutta, P. (2013). Simulation Study of an Integrated Reverse Logistics in Fuzzy Environment. IAENG Transactions on Engineering Technologies, 186, 151-165.

Das, K., Posinasetti, N. R. (2015). Addressing environmental concerns in closed loop supply chain design and planning. International Journal of Production Economics 163, 34-47.

Dejonckheere, J., Disney, S. M., Lambrecht, M. R. (2003). Measuring and avoiding the bullwhip effect : A control theoretic approach. European Journal of Operational Research 147 (3), 567-590.

Denyer, D., Tranfield, D. (2009). Producing a systematic review. In D. A. Buchanan \& A. Bryman (Eds.), The SAGE handbook of organizational research methods (pp. 671-689). London: Sage Publications Ltd.

Ding, X., Gan, X. (2009). System Dynamics Model to Analysis Oscillation and Amplification in the Closed-Loop Supply Chain. International Conference on Management of E-Commerce and E-Government, 343-346.

Disney, S. M., Lambrecht, M. R. (2008). On Replenishment Rules, Forecasting and the Bullwhip Effect in Supply chains. Foundations and Trends in Technology, Information and Operations Management 2(1), 1-80.

Disney, S., Towill, D., (2003). On the bullwhip and inventory variance produced by an ordering policy. Omega 31 (3), $157-167$.

Disney, S.M, Lambrecht, M.R., 2008. On Replenishment Rules, Forecasting, and the Bullwhip Effect in Supply Chains. Foundations and Trends in Technology, Information and Operations Management, 2 (1), 1-80.

Dominguez, R., Cannella, S., Framinan, J.M. 2015. On returns and network configuration in supply chain dynamics. Transportation Research Part E: Logistics and Transportation Review 73, 152-167.

Elkington, J., 2002. Cannibals with forks: the triple bottom line of 21st century business (Reprint ed.), Capstone, Oxford.

Eskandarpour, M., Dejax, P., Miemczyk, J., Péton, O. (2015). Sustainable supply chain network design: an optimization-oriented review. Omega 54, 11-32.

Forrester, J. W. (1961). "Industrial Dynamics", MIT Press: Cambridge, Massachusetts.

Ge, R. \& Huang, X. (2009). "Closed-loop supply chain switching model with outsourcing selection and its robust control”, Computer Integrated Manufacturing Systems -Beijing-; 15, 10, pp. 5.

Geary, S., Disney, S.M., Towill, D.R., 2006. On bullwhip in supply chains - Historical review, present practice and expected future impact. International Journal of Production Economics 101 (1): 2-18.

Georgiadis, P., Besiou, M., 2008. Sustainability in electrical and electronic equipment closed-loop supply chains: A System Dynamics approach. Journal of Cleaner Production 16 (15), pp. 1665-1678.

Gong, Y., Huang, D., Wang, E., Peng, Y. (2009). A Fuzzy Chance Constraint Programming Approach for Location-allocation Problem under Uncertainty in a Closed-loop Supply Chain. International Joint Conference on Computational Sciences and Optimization, $837-841$.

Govindan, K., Jafarian, A., Khodaverdi, R., Devika, K. (2014). Two-echelon multiple-vehicle location-routing problem with time windows for optimization of sustainable supply chain network of perishable food. International Journal of Production Economics $152,9-28$.

Guide Jr, V. D. R., Van Wassenhove, L. N. (2009). OR FORUM-the evolution of closed-loop supply chain research. Operations research 57 (1), 10-18.

Guide, V., Van Wassenhove, L., 2009. The Evolution of Closed-Loop Supply Chain Research. Operations Research 57 (1), $10-18$.

Guo, H. (2008a). H-infinity Control of Bullwhip Effects in Closed-loop Supply Chain Networks with Two Chains Cooperation. $7^{\circ}$ World Congress on Intelligent Control and Automation, 2206-2211.

Guo, H. (2008b). LMI-based H $\infty$ Control of Closed-loop Supply Chain Dynamic Model with Two Chains Cooperation. International Seminar on Future BioMedical Information Engineering, FBIE'08, 255-258.

Guo, H. (2010). LMI-based Ho control of CLSC networks with the third party reverse provider. International Conference on Measuring Technology and Mechatronics Automation (ICMTMA), 587-590. 
Guo, H. (2010). LMI-Based H-infinity Control of CLSC Networks with the Third Party Reverse Provider. International Conference on Measuring Technology and Mechatronics Automation, 587-590.

Guo, H., Huang, X.-Y. (2006a). Hळ Control of a State Matrix Model of Closed-loop Supply Chain and its Bullwhip Effect. 9th International Conference on Control, Automation, Robotics and Vision, 1-5.

Guo, H., Huang, X.-Y. (2006b). A Robust H $\alpha$ Control Method for Analyzing the Bullwhip Effect of the Reverse Logistics Supply Chain. International Conference on Management Science and Engineering, 2006. ICMSE'06, 242-245.

Guo, H., Sun, B. (2010). H-infinity Control for Dual-Channel Closed-Loop Supply Chain Model with B2B E-market and Reverse Logistics. Third International Conference on Intelligent Networks and Intelligent Systems, 353-356.

Guo, H., Xu, J. W. (2008). Remanufacturing system model and H control of its bullwhip effect. Shu Systems Engineering and Eletronics, 30 (5), 914-916.

Guo, H., Zhu, Y., Zhou, X., Hai, S. (2008). H $\infty$ Control of Two Chains CLSC Networks with the Third Party Reverse Provider and Its Bullwhip Effect. International Conference of Production and Operation Management, 256-261

Hao, H. (2011). Research on time-efficiency oriented mechanism of after-sale service logistics operation: China's automobile maintenance industry as example. Advanced Materials Research 179, 1037-1041

He, Y. (2015). Acquisition pricing and remanufacturing decisions in a closed-loop supply chain. International Journal of Production Economics 163, 48-60.

Hua, H. (2009). Analysis of the Bullwhip in a selection and its robust control Manufacturing/Remanufacturing. International Symposium on Information Engineering and Electronic Commerce, 646-649.

Huang, L., Liu, Y. (2008). Supply Chain Dynamics under the Sustainable Development. 4th International Conference on Wireless Communications, Networking and Mobile Computing, 1-6.

Jayaram, J., Avittathur, B. (2015). Green supply chains: A perspective from an emerging economy. International Journal of Production Economics 164, 234-244.

Jing, Y.a , Wang, X.a , Li, W.b , Deng, L.a, (2013). Simulation and PID control of bullwhip effect in closed-loop supply chain based on noise bandwidth. International Journal of Applied Mathematics and Statistics, 41 (11). 286-294.

John, S., Naim, M. M., Towill, D. R., (1994). Dynamic analysis of a WIP compensated decision support system. International Journal of Manufacturing System Design 1 (4), 283-297.

Kleijnen, J.P.C., Smits, M.T., 2003. Performance metrics in supply chain management. Journal of the Operational Research Society, $54(5), 507-514$.

Kumar, N., Vrat, P. (1994). A simulation study of unit exchange spares management of diesel locomotives in the Indian Railways. International Journal of Production Economics 33 (1), 225-236.

Lalwani, C.S., Disney, S.M. Towill, D.R., (2006). Observable and controllable state space representations of a generalized Order-UpTo policy. International Journal of Production Economics, 101 (1), 173-184.

Lee, H. L., Padmanabhan, V., Whang, S., (1997). Information distortion in a supply chain: the bullwhip effect. Management Science 43 (4), 546-558.

Lehr, C.B., Thun, J.-H., Milling, P.M. (2013). From waste to value - A system dynamics model for strategic decision-making in closedloop supply chains. International Journal of Production Research 51 (13), 4105-4116.

Meixell, M. J., Luoma, P. (2015). Stakeholder pressure in sustainable supply chain management: a systematic review. International Journal of Physical Distribution \& Logistics Management, 45(1/2), 69-89.

Paksoy, T., Bektaş, T., Özceylan, E. (2011). Operational and environmental performance measures in a multi-product closed-loop supply chain. Transportation Research Part E: Logistics and Transportation Review 47 (4), 532-546.

Pati, R. K., Vrat, P., \& Kumar, P. (2010). Quantifying bullwhip effect in a closed loop supply chain. Opsearch, 47 (4), $231-253$.

Qiang, Q., Ke, K., Anderson, T., Dong, J. (2013). The closed-loop supply chain network with competition, distribution channel investment, and uncertainties. Omega 41 (2), 186-194.

Qingli, D., Hao, S., \& Hui, Z., (2008). Simulation of Remanufacturing in Reverse Supply Chain Based on System Dynamics. International Conference on Service Systems and Service Management, 1-6.

Ramezani, M., Kimiagari, A. M., Karimi, B. (2014). Closed-loop supply chain network design: A financial approach. Applied Mathematical Modelling 38 (15), 4099-4119. 
Seuring, S., Müller, M., 2008. From a literature review to a conceptual framework for sustainable supply chain management. Journal of Cleaner Production, 16 (15), 1699-1710.

Shi, L., Sheng, Z., Xu, F. 2015. Complexity analysis of remanufacturing duopoly game with different competition strategies and heterogeneous players. Nonlinear Dynamics, 1-12.

Srivastava, S. K. (2007). Green supply-chain management: A state-of-the-art literature review. International Journal of Management Reviews 9 (1), 53-80.

Srivastava, S., (2008). Network design for reverse logistics. Omega 36 (4), 535-548.

Syntetos, A.A., Georgantzas, N.C., Boylan, J.E., Dangerfield, B.C. (2011). Judgement and supply chain dynamics. Journal of the Operational Research Society 62 (6), 1138-1158.

Tang, O., Naim, M. M. (2004). The impact of information transparency on the dynamic behaviour of a hybrid manufacturing/remanufacturing system. International Journal of Production Research 42(19), 4135-4152.

Tejeida, R., Flores-Cadena, M., Morales-Matamoros, O. (2010). Analyzing the bullwhip effect in after-sales spare parts supply chains in telecom firms, a complex system approach. Proceedings of the 54th Annual Meeting of the ISSS-2010, 54 (1).

Towill, D.R., Zhou, L., Disney, S.M., (2007). Reducing the bullwhip effect: looking through the appropriate lens. International Journal of Production Economics 108 (1-2), 444-453.

Turrisi, M., Bruccoleri, M., \& Cannella, S. (2013). "Impact of reverse logistics on supply chain performance", International Journal of Physical Distribution \& Logistics Management, 43(7), 564-585.

Ventana Systems Inc. 2006. The Ventana Simulation Environment: VENSIM 5.5D, Ventana Systems Inc., Cambridge, MA, USA.

Wan, Z., \& Li, C. (2012). Bullwhip effect in closed-loop supply chain based on system dynamics. Computer Integrated Manufacturing Systems, 18(5), 1093-1098.

Wang, C., Ding, X. (2009). Analysis on the Impact of Reverse Logistics on the Dynamic Behaviors in a Two-stage Supply Chain. International Conference on Management of e-Commerce and e-Government, 339-342.

Wu, Y., Tang, D. (2010). Analysis on Impact Factors of Bullwhip Effect in Closed-Loop Supply Chain for Recycling and Utilization. International Conference on Engineering and Business Management, 2590-2593.

Xiong, J.a , Zhang, M.a , Ji, Y.b , Gao, Y.a (2010). Analysis on the impact of the-third-party on the bullwhip effect in the closed-loop logistics. International Conference on E-Business and E-Government (ICEE), 3738 - 3740.

You, J.-X., Sui, M.-G., Huo, J.-Z. (2007). Bullwhip Effect in Closed Loop Supply Chain. System Engineering Theory and Practice 27(12), 111-116

Yuan, X.G., Zhang, X.Q. 2015. Recycler reaction for the government behavior in closed-loop supply chain distribution network: Based on the system dynamics. Discrete Dynamics in Nature and Society, 2015, 206149.

Zanoni, S., Ferretti, I., Tang, O. (2006). Cost performance and bullwhip effect in a hybrid manufacturing and remanufacturing system with different control policies. International Journal of Production Research 44 (18-19), 3847-3862.

Zhang, X. (2011). Bullwhip effect reduction in closed-loop supply chains using H-infinity control- International Conference on Management Science and Industrial Engineering (MSIE), 659-663.

Zhao, X., Huang, P., Mai, Y. (2005). The Dynamic Behavior Analysis on Single-echelon Supply Chain System with Product Returns. Journal-Shanghai Jiaotong University -Chinese Edition- 39 (10), 1635-1639

Zhou, L., Disney, S. M., Lalwani, C. S. (2004). Reverse Logistics: a study of bullwhip in continuous time. Processing World Congress on Intelligent Control and Automation (WCICA) 4, 3539-3542.

Zhou L., Xu S.-J., Disney S.M. (2005). Analysis and optimization of inventory variance and bullwhip in a manufacturing/remanufacturing system. Journal of Shanghai Jiaotong University 39 (10), 1587-1591.

Zhou, L., Disney, S. M. (2006). Bullwhip and inventory variance in a closed loop supply chain. OR Spectrum 28 (1), $127-149$.

Zhou, L., Naim, M. M., Towill, D. R. (2006). Dynamic performance of a hybrid inventory system with a Kanban policy in remanufacturing process. Omega 34 (6), 585-598. 
Cannella S. Bruccoleri M., Framinan J.M. 2016. Closed-loop supply chains: What reverse logistics factors influence performance? International Journal of Production Economics 175, 35-46 - DOI: 10.1016/j.ijpe.2016.01.012

Zhou W., Piramuthu S. (2013). Remanufacturing with RFID item-level information: Optimization, waste reduction and quality improvement. International Journal of Production Economics 145 (2), 647-657. 